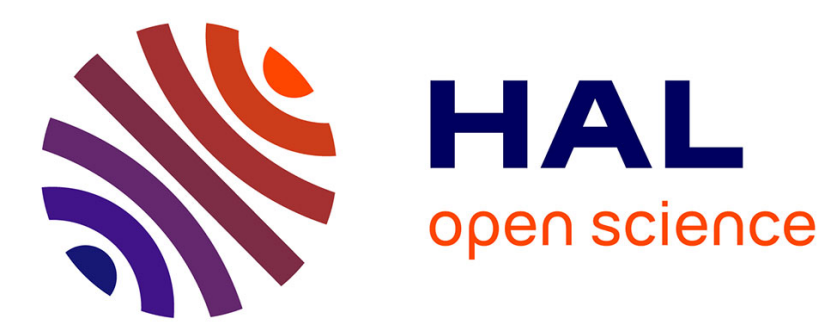

\title{
Fluorogenic Probing of Membrane Protein Trafficking
}

Chenge Li, Aurélien Mourton, Marie-Aude Plamont, Vanessa Rodrigues, Isabelle Aujard, Michel Volovitch, Thomas Le Saux, Franck Perez, Sophie Vriz, Ludovic Jullien, et al.

\section{- To cite this version:}

Chenge Li, Aurélien Mourton, Marie-Aude Plamont, Vanessa Rodrigues, Isabelle Aujard, et al.. Fluorogenic Probing of Membrane Protein Trafficking. Bioconjugate Chemistry, 2018, 29 (6), pp.18231828. 10.1021/acs.bioconjchem.8b00180 . hal-01919676

\section{HAL Id: hal-01919676 https://hal.science/hal-01919676}

Submitted on 12 Nov 2018

HAL is a multi-disciplinary open access archive for the deposit and dissemination of scientific research documents, whether they are published or not. The documents may come from teaching and research institutions in France or abroad, or from public or private research centers.
L'archive ouverte pluridisciplinaire $\mathbf{H A L}$, est destinée au dépôt et à la diffusion de documents scientifiques de niveau recherche, publiés ou non, émanant des établissements d'enseignement et de recherche français ou étrangers, des laboratoires publics ou privés. 


\section{Fluorogenic probing of membrane protein trafficking}

Chenge $\mathrm{Li}^{1}$, Aurélien Mourton ${ }^{2,3}$, Marie-Aude Plamont ${ }^{1}$, Vanessa Rodrigues ${ }^{1}$, Isabelle Aujard $^{1}$, Michel Volovitch ${ }^{2,4}$, Thomas Le Saux ${ }^{1}$, Franck Perez ${ }^{5}$, Sophie Vriz ${ }^{2,6}$, Ludovic Jullien ${ }^{1}$, Alain Joliot $^{2} \&$ Arnaud Gautier ${ }^{1, *}$

1 PASTEUR, Département de Chimie, École Normale Supérieure, PSL University, Sorbonne Université, CNRS, 75005 Paris, France.

${ }^{2}$ Center for Interdisciplinary Research in Biology (CIRB), Collège de France, CNRS, INSERM, PSL Research University, Paris, France

${ }^{3}$ PSL Research University, Paris, France

${ }^{4}$ École Normale Supérieure, PSL Research University, Department of biology, Paris, France

${ }^{5}$ Institut Curie, PSL Research University, CNRS UMR144, 26 rue d'Ulm, 75248 Paris Cedex 05, France

${ }^{6}$ Université Paris Diderot, Sorbonne Paris Cité, Biology Department - 75205 Paris Cedex 13 - France

* Correspondence should be addressed to: arnaud.gautier@ens.fr 


\section{ABSTRACT}

Methods to differentially label cell-surface and intracellular membrane proteins are indispensable for understanding their function and the regulation of their trafficking. We present an efficient strategy for the rapid and selective fluorescent labeling of membrane proteins based on the chemical-genetic fluorescent marker FAST (fluorescence-activating and absorption-shifting tag). Cell-surface FAST-tagged proteins could be selectively and rapidly labeled using fluorogenic membraneimpermeant 4-hydroxybenzylidene rhodanine (HBR) analogs. This approach allows the study of protein trafficking at the plasma membrane with various fluorometric techniques, and opens exciting prospects for the high-throughput screening of small molecules able to restore disease-related trafficking defects. 


\section{MAIN TEXT}

Plasma membrane resident proteins are in charge of vital functions for cells and organisms. Membrane receptors relay external signals inside cells. Transporters are involved in the movement of ions, small molecules and macromolecules across the cell membrane. Cell adhesion molecules dictate how cells interact with other cells or with the extracellular matrix. Defects within the trafficking of membrane proteins are associated with many important diseases. Tools that enable simple and efficient study of the secretion, transportation and recycling of membrane proteins are thus fundamental for both understanding membrane protein functions and developing innovative cell assays for the discovery of small molecules able to restore genetic mutation-induced trafficking defects.

Discriminating a protein of interest at the cell-surface from the same protein inside cell requires effective and selective fluorescence labeling methods. Ideal fluorescent probes for labeling cell-surface proteins (i) are unable to cross membranes, and (ii) allow instantaneous and wash-free labeling in order to quantify cell-surface protein levels by simple add-and-read protocols. Rapid wash-free labeling protocols are crucial to minimize any artefactual events of secretion, transportation or recycling that could occur during the labeling and washing steps. In this context, the use of small fluorogenic probes that are membrane-impermeant and non-fluorescent until labeling occurs are thus highly attractive for labeling cell-surface membrane proteins. Membrane-impermeant fluorogenic substrates for self-labeling tags such as SNAP$\operatorname{tag}^{1-3}$ and PYP-tag ${ }^{4}$ allowed wash-free covalent labeling of cell-surface fusion proteins. These approaches requires however several tens of minutes for reaching 
A

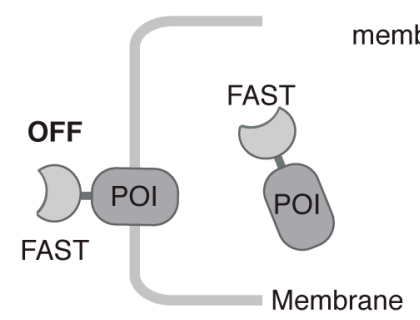

mbrane-impermeant

$$
\text { fluorogen }
$$
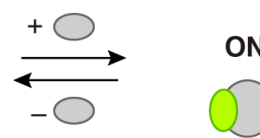

FAST:fluorogen

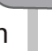

Membrane

B
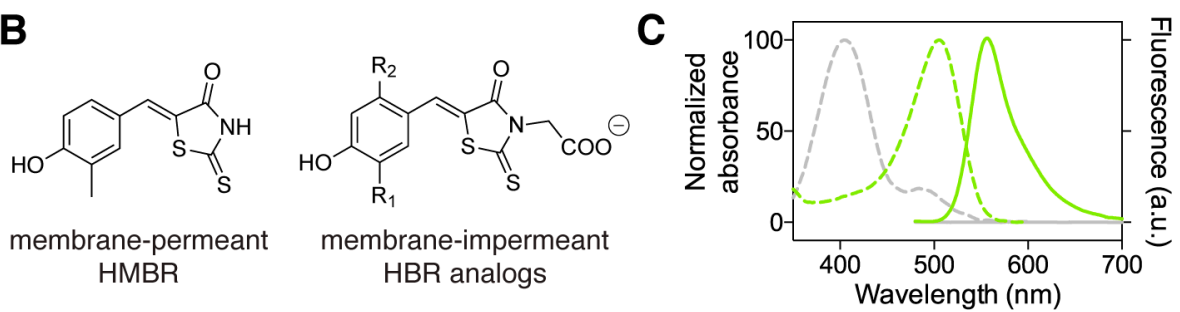

Figure 1. Selective labeling of cell-surface FAST-tagged proteins. (A) Principle. (B) Structures of the membrane-permeant HMBR and of the membrane-impermeant HBR analogs: HBRAA-3M $\left(R_{1}=M e, R_{2}=H\right)$, HBRAA-3E $\left(R_{1}=E t, R_{2}=H\right)$, HBRAA$2,5 \mathrm{DM}\left(\mathrm{R}_{1}=\mathrm{Me}, \mathrm{R}_{2}=\mathrm{Me}\right), \mathrm{HBRAA}-2 \mathrm{OM}\left(\mathrm{R}_{1}=\mathrm{H}, \mathrm{R}_{2}=\mathrm{OMe}\right), \mathrm{HBRAA}-3 \mathrm{OE}\left(\mathrm{R}_{1}=\mathrm{OEt}\right.$, $\mathrm{R}_{2}=\mathrm{H}$ ). (C) Absorption (dashed line, left axis) and emission (solid line, right axis) spectra of free HBRAA-3E (grey line) and of FAST:HBRAA-3E complex (green line) in phosphate buffer saline $\mathrm{pH} 7.4$ at $25^{\circ} \mathrm{C}$.

complete labeling, reducing consequently the temporal resolution. Fluorogenactivating proteins (FAPs) derived from $25-30 \mathrm{kDa}$ single-chain antibodies binding noncovalently and activating the fluorescence of membrane-impermeant far-red fluorogenic malachite green derivatives proved to allow rapid fluorescent labeling of cell-surface proteins ${ }^{5-12}$.

In order to broaden the toolbox available for the study of membrane proteins, in particular in terms of spectral properties and tag size, we developed an approach based on a new generation of chemical-genetic fluorescent markers called FAST (fluorescence-activating and absorption-shifting tag), which has been recently developed for the selective labeling of fusion proteins in living cells ${ }^{13}$. FAST is a small $14 \mathrm{kDa}$ protein tag evolved to form non-covalent and reversible fluorescent complexes with cell-permeant and non-toxic 4-hydroxybenzylidene rhodanine (HBR) analogs ${ }^{13,14}$. 
Because they fluoresce only when immobilized within FAST (because of conformational locking) and undergo an $>80 \mathrm{~nm}$ red-shift in absorption upon binding (due to selective binding of their anionic form), HBR analogs do not exhibit nonspecific fluorescence in cells, enabling to image without the need for washing. FAST was shown to be functional in various subcellular localizations and expression systems (e.g. bacteria, yeast, mammalian cells) including multicellular organisms (e.g. zebrafish embryo $)^{13}$. An important feature of FAST is the ability to tune its properties by changing the chemical structure of the applied fluorogen ${ }^{14}$. To further extend its use for the selective detection of cell-surface proteins (Figure 1A), we developed fluorogens able to form fluorescent complexes with FAST, but incapable of crossing the plasma membrane. These membrane-impermeant fluorogens allowed us to develop an efficient and simple add-and-read labeling protocol to study protein trafficking by various quantitative fluorometric techniques.

Table 1. Physico-chemical properties of FAST:fluorogen complexes in PBS pH 7.4. Abbreviations are as follows: $\lambda_{\text {abs, }}$ wavelength of maximal absorption; $\Delta \lambda_{\text {abs }}=$

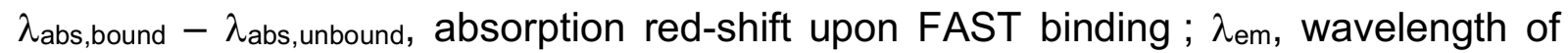
maximal emission; $\varepsilon$, molar absorption coefficient at $\lambda$ abs; $\phi$, fluorescence quantum

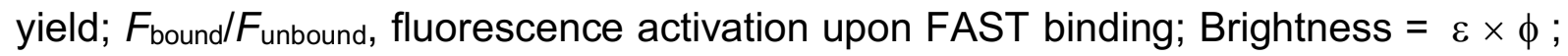
$K_{\mathrm{D}}$ thermodynamic dissociation constant.

\begin{tabular}{lcccccccc}
\hline Complex & $\begin{array}{c}\lambda_{\text {abs }} \\
\mathrm{nm}\end{array}$ & $\begin{array}{c}\Delta \lambda_{\text {abs }} \\
\mathrm{nm}\end{array}$ & $\begin{array}{c}\lambda \text { em } \\
\mathrm{nm}\end{array}$ & $\begin{array}{c}\varepsilon \\
\mathrm{mM}^{-1} \mathrm{~cm}^{-1}\end{array}$ & $\begin{array}{c}\phi \\
\%\end{array}$ & $F_{\text {bound }} / F_{\text {unbound }}$ & Brightness & $\begin{array}{c}K_{\mathrm{D}} \\
\mu \mathrm{M}\end{array}$ \\
FAST:HMBR & 481 & 80 & 540 & 45 & 23 & 300 & 10,300 & 0.13 \\
FAST:HBRAA-3M & 502 & 56 & 557 & 56 & 6 & 280 & 3,400 & 6.4 \\
FAST:HBRAA-2OM & 497 & 55 & 537 & 55 & 5 & 130 & 2,800 & 0.48 \\
FAST:HBRAA-2,5DM & 519 & 63 & 566 & 63 & 5 & 180 & 3,200 & 5.4 \\
FAST:HBRAA-3E & 505 & 61 & 559 & 61 & 8 & 220 & 4,900 & 1.3 \\
FAST:HBRAA-3OE & 525 & 62 & 575 & 62 & 6 & 110 & 3,700 & 1.7 \\
& & & & & & & &
\end{tabular}

HBR analogs are mainly neutral at physiological $\mathrm{pH}$ and highly membrane-permeant.

To prevent membrane crossing and restrain protein labeling to the cell surface, we introduced a negative charge by tethering a carboxymethyl group (deprotonated at 
physiological $\mathrm{pH}$ ) to the rhodanine head (Figure 1B). As the brightness of FAST:fluorogen complexes depends furthermore on the ability of the protein cavity to lock the fluorogen in an emissive conformation, we synthesized carboxymethylated HBR analogs with various steric demands by varying the substituents on the aromatic ring (Figure 1B and Figure S1). The synthesized carboxymethylated fluorogens (i) showed micromolar affinities for FAST compatible with efficient labeling in live cells, and (ii) formed fluorescent complexes with FAST (Figure 1C and Table 1). As expected from other HBR analogs ${ }^{13,14}$, upon binding to FAST the reported fluorogens underwent both a red-shift in absorption (of about $60 \mathrm{~nm}$ ) due to specific binding of the deprotonated fluorogen and a large fluorescence increase (from 110 to 280-fold) that ensures high signal-to-background ratio (Figure $1 \mathrm{C}$ and Table 1).

Based on its binding and brightness performance, we focused on HBRAA-3E for cell validation. We first showed that HBRAA-3E was non-toxic for mammalian cells by determining cell viability after $24 \mathrm{~h}$ of incubation (Figure S2). We next verified cell exclusion after prolonged exposure. We expressed FAST fused to the red fluorescent protein mCherry in the cytoplasm of HeLa cells. Cells were then incubated for two hours with media containing $5 \mu \mathrm{M}$ HBRAA-3E. Confocal imaging revealed no intracellular labeling of FAST (Figure 2A), attesting the cell exclusion of HBRAA-3E within this extended time window.

Next, we evaluated the selective labeling of cell-surface FAST-tagged proteins with HBRAA-3E. We transiently expressed in HeLa cells a secreted transmembrane FAST fusion protein sFASTtm1, which consists in FAST fused at the N-terminus to the murine $\lg \kappa$-chain leader sequence and at the C-terminus to the platelet derived growth 

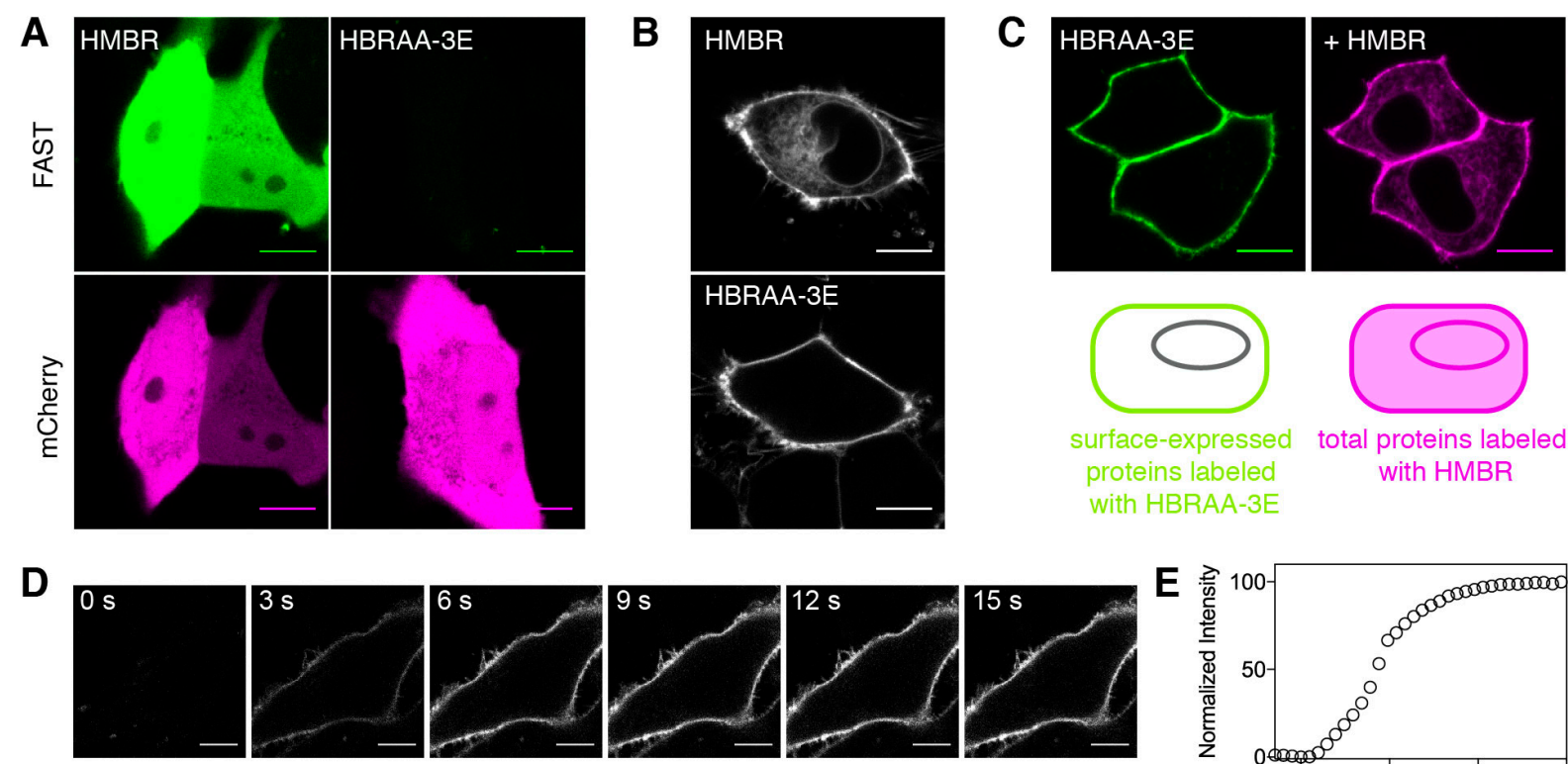

Figure 2. Specific cell-surface protein labeling. (A) Confocal micrographs of HeLa cells expressing FAST-mCherry treated with $5 \mu \mathrm{M}$ HBRAA-3E for $2 \mathrm{~h}$ (right). As control, cells were incubated with $5 \mu \mathrm{M}$ of the membrane-permeant HMBR for $15 \mathrm{~s}$ (left). Sideby-side images were recorded using identical settings (Green: Ex/Em 488/493-575 nm; Magenta: Ex/Em 543/615-797 nm). (B) HeLa cells expressing a secreted transmembrane FAST fusion protein (sFASTtm1) incubated for 5 min with $5 \mu \mathrm{M}$ of HMBR (top) or $5 \mu \mathrm{M}$ of HBRAA-3E (bottom). Ex/Em 488/493-575 nm. (C) False-color images of HeLa cells expressing sFASTtm1 (Ex/Em 488/493-575 nm). Cells were imaged after $1 \mathrm{~h}$ of incubation with $5 \mu \mathrm{M}$ HBRAA-3E (green image). Subsequent addition of $5 \mu \mathrm{M}$ membrane-permeant HMBR and immediate imaging revealed the total pool of proteins (magenta image) expressed at the surface and within the secretory pathway. Note that the detection settings were adjusted to take into account the difference of brightness of FAST:HBRAA-3E and FAST:HMBR. (D,E) The labeling of sFASTtm1 by addition (at $t=0 \mathrm{~s}$ ) of $5 \mu \mathrm{M}$ HBRAA-3E was followed by time-lapse microscopy (D). The graph shown in (E) presents the corresponding quantified labeling kinetics. All scale bars are $10 \mu \mathrm{m}$.

factor receptor (PDGFR) transmembrane domain, with the FAST domain facing the extracellular space. While transfected cells treated with the membrane permeant 4hydroxy-3-methylbenzylidene rhodanine (HMBR) were labeled both at the plasma membrane and within the secretory/recycling pathway, the labeling was restricted to the plasma membrane in cells treated with HBRAA-3E (Figure 2B), in agreement with HBRAA-3E cell exclusion. 
As HMBR binds FAST more tightly than HBRAA-3E, we anticipated that HMBR could dynamically replace bound HBRAA-3E, allowing one to detect and quantify in the same experiment the extracellular and the total pool of FAST-tagged protein (Figure 2C). We previously demonstrated such replacement with fluorogens displaying different spectral properties ${ }^{14}$. As FAST:HMBR and FAST:HBRAA-3E could not be distinguished spectrally, we exploited the difference of brightness of the two complexes to demonstrate the replacement. Replacement of HBRAA-3E-containing cell medium with HMBR-containing cell medium led to an increase of membrane fluorescence in agreement with the higher brightness of FAST:HMBR (Figure S3). To demonstrate complete replacement, cells were washed to unlabel FAST, and were next treated only with HMBR: this second HMBR addition led to fluorescence levels identical to those observed after the first HMBR addition (Figure S3), demonstrating that HMBR did replace HBRAA-3E dynamically.

Next, we analyzed labeling kinetics by time-lapse microscopy. Analysis of HeLa cells expressing sFASTtm1 showed that labeling of sFASTtm 1 with $5 \mu \mathrm{M}$ of HBRAA-3E was complete within $10 \mathrm{~s}$ (Figure 2D,E and Movie S1), which corresponds to our knowledge to one of the fastest kinetics ever reported for cell-surface protein labeling.

The fast labeling kinetics showed us that FAST was well suited for the development a simple add-and-read protocol for the quantification of cell-surface proteins. Next, we developed a protocol for the study of protein trafficking by flow cytometry. Flow cytometry has the advantage of enabling easy and unbiased statistical analysis with a higher throughput than microscopy. We anticipated that the ability to quantify in parallel the amount of surface protein with membrane impermeant HBRAA-3E and the total 


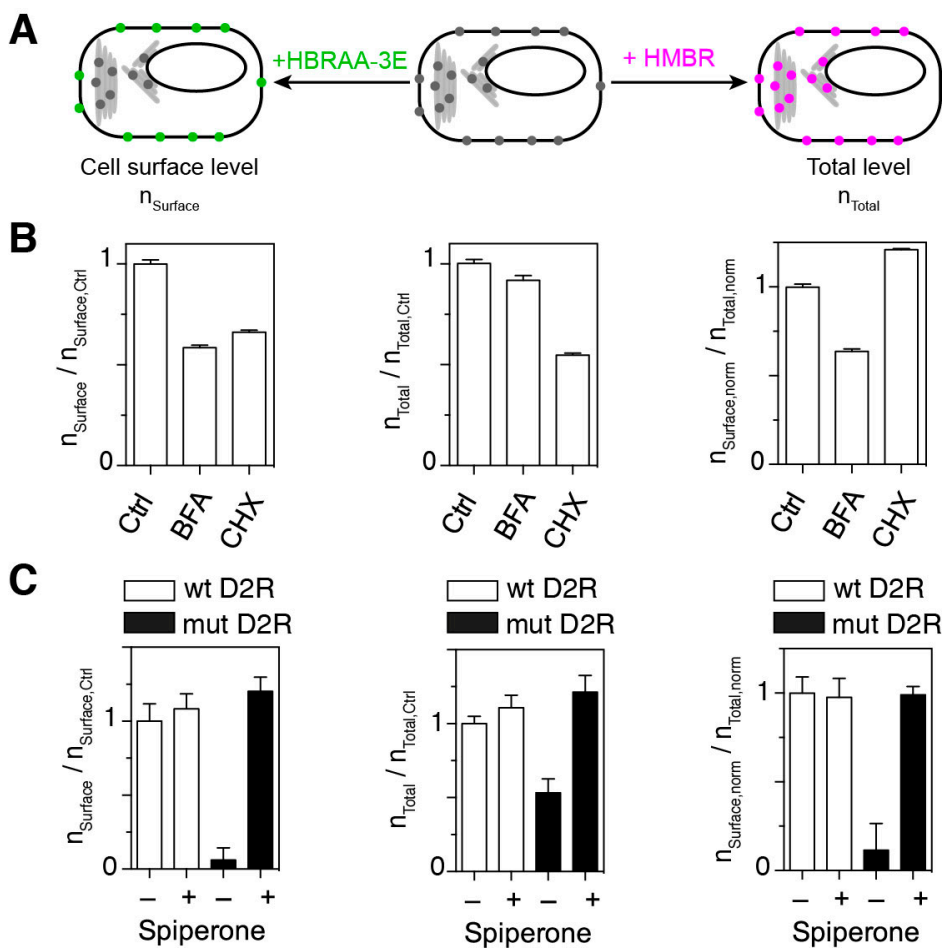

Figure 3. Study of membrane protein trafficking. (A) Labeling with membrane impermeant HBRAA-3E and membrane-permeant HMBR allow to quantify the amount of cell surface proteins and the total amount of proteins. (B) HeLa cells expressing sFASTtm2 were treated for $6 \mathrm{~h}$ with control vehicle (Ctrl), Brefeldin A (BFA) or Cycloheximide (CHX), and analyzed by flow cytometry after addition of HBRAA-3E or HMBR. (C) HeLa cells expressing wild-type Dopamine Receptor D2 (wt D2R) or its defective mutant (mut D2R) fused to FAST were treated for $24 \mathrm{~h}$ without $(-)$ or with $(+)$ Spiperone, and analyzed by flow cytometry after addition of HBRAA-3E or HMBR. $(B, C)$ The fluorescence of HBRAA-3E-treated cells and HMBR-treated cells provided the normalized cell-surface protein level $n_{\text {surface, norm }}=n_{\text {Surface }} / n_{\text {Surface, }, \text { trr }}\left(n_{\text {Surface }}=\right.$ number of proteins at the surface, $\mathrm{n}_{\text {Surface, } \mathrm{Ctrl}}=$ number of proteins at the surface in the control $)$ and the normalized total protein level $n_{\text {Total, norm }}=n_{\text {Total }} / \mathrm{n}_{\text {Total, Ctrl }}\left(\mathrm{n}_{\text {Total }}=\right.$ total number of proteins, $\mathrm{n}_{\text {Total, Ctrl }}=$ total number of proteins in the control) (See SI Text 1). Shown data are mean \pm standard deviation of 3 independent experiments.

protein amount with membrane-permeant HMBR, both interacting with the very same site within FAST, should allow the accurate ratiometric determination of surfaceexpressed proteins (Figure 3A, see SI Text 1 for the theoretical framework for the quantification of cell surface protein level). Note that, for screening applications, splitting the cell population in two groups that are labeled with either membrane impermeant HBRAA-3E or membrane-permeant HMBR are preferred over a replacement strategy based on the sequential labeling with HBRAA-3E and then with 
HMBR, because parallel treatment allows quasi-simultaneous analysis of the two conditions and simplifies screening implementation. To test our approach, we expressed in HeLa cells a secreted transmembrane FAST fusion protein sFASTtm2, which contains the IL2 leader sequence upstream FAST, and the transmembrane fragment of human CD4 (aa 393-428) downstream. After 24 h of expression, cells were treated for $6 \mathrm{~h}$ with the drug Brefeldin A that inhibits canonical protein secretion ${ }^{15}$, or with Cycloheximide that blocks protein synthesis ${ }^{16}$. Cells were labeled by addition of HBRAA-3E or HMBR, and then directly analyzed by flow cytometry without washing. Both Brefeldin A and Cycloheximide induced a two-fold decrease of surface sFASTtm2 accumulation revealed with HBRAA-3E (Figure 3B). By contrast, only Cycloheximide treatment impaired the total amount of sFASTtm2 quantified with membrane-permeant HMBR (Figure 3B). This experiment illustrated how Brefeldin A specifically acts on protein trafficking, while Cycloheximide decreases the global protein pool irrespectively of its localization or trafficking property (Figure 3B). Taken together, these results demonstrated that our approach enables to (i) screen for drugs impacting cell-surface protein secretion and (ii) discriminate between defects in protein trafficking or in protein synthesis/turnover.

The discovery of small molecules able to restore trafficking defects induced by genetic mutations has become highly important in drug design ${ }^{17}$. Validating the ability of a small molecule to restore normal traffic requires spatial information that is classically provided by microscopy and image analysis, limiting thus screening throughput. Methods to interrogate protein trafficking using technologies more suitable for high throughput analysis such as spectrofluorimetry or flow cytometry, are thus needed ${ }^{18}$. To address the relevance of our strategy for screening drugs able to rescue cell- 
surface expression, we used the human D2 dopamine receptor (D2R) as a model of GPCR ${ }^{11}$. Mutations in the DRY motif at the end of the transmembrane-domain (TM)3 in GPCRs are known to contribute to diseases by (i) constitutive receptor activation and internalization, and (ii) retention of misfolded receptors in the endoplasmic reticulum (ER) ${ }^{19-21}$. D2R and a DRY-to-AAY D2R mutant (mutD2R) fused to an extracellular FAST were expressed in HeLa cells. We verified by confocal microscopy that cells labeled with membrane-impermeant HBRAA-3E showed membranelocalized FAST-D2R, while no fluorescence signal could be detected for FASTmutD2R, in agreement with a trafficking defect (Figure S4). Subsequent addition of membrane-permeant HMBR revealed that FAST-mutD2R was retained in the ER as expected (Figure S4). The cell surface accumulation of FAST-mutD2R could be rescued by addition of Spiperone, a D2R antagonist previously reported to act as pharmacological chaperone ${ }^{11}$ (Figure S4). With this model system in hand, we next quantified the rescue of cell-surface FAST-mutD2R expression by flow cytometry. Cells expressing FAST-D2R and FAST-mutD2R were labeled with either membraneimpermeant HBRAA-3E or membrane-permeant HMBR in order to determine the fraction of cell-surface expressed receptors. Flow cytometry analysis showed a tenfold lower cell-surface expression of FAST-mutD2R relative to wild-type FAST-D2R (Figure 3C), in agreement with a strong trafficking defect. Addition of Spiperone restored cell-surface FAST-mutD2R levels to wild-type ones (Figure 3C). In addition, we evidenced that (i) part of the loss of cell-surface expression of mutD2R resulted from a two-fold reduction of the total mutD2R level, and that (ii) Spiperone restored normal level, possibly by preventing degradation through stabilization of the receptor upon ligand binding or by limiting aggregation. Taken together, these experiments demonstrated that the combined use of membrane-impermeant and membrane- 
permeant fluorogens was very well-suited to quantify trafficking restoration without the need for imaging, opening great prospects for high-throughput screening of small molecules able to correct genetic disorders of protein trafficking.

In this paper, we present a general method allowing the selective fluorescent labeling of cell-surface proteins. We used a small and versatile protein tag of $14 \mathrm{kDa}$, FAST, that forms a fluorescent complex with HBR analogs ${ }^{13,14}$. Compared to other fluorogenic tagging systems such as FAPs, which are single-chain variable fragments of 25-30 $\mathrm{kDa}$, FAST has the advantages of being disulfide-free and significantly smaller (only $14 \mathrm{kDa}$ ). Disulfide-free tags ensure full activity no matter the redox conditions and cell localization (which is crucial for proteins that traffic through various localizations), providing greater experimental versatility. The size of tags is, on the other hand, a general concern among biologists. Smaller tags are in general preferable as they minimize potential interference with protein localization and function. As the modular bipartite nature of the FAST:fluorogen interaction allows to modulate the properties of the genetically encoded FAST reporter by changing the structure of the applied fluorogen ${ }^{14}$, we functionalized HBR analogs with a negatively charged carboxymethyl group in order to prevent membrane crossing and restrain protein labeling to the cell surface. This singular property permits to obtain spatial information on FAST-tagged proteins by a simple measurement of fluorescence, without the need for microscopy and image analysis. We developed an efficient protocol to quantify the surface display level of FAST-tagged membrane proteins by flow cytometry, a method allowing high throughput statistical analysis. Compared to labor-intensive and multistep protocols based on immunostaining or covalent labeling, our fluorogenic approach boils down to a single addition of fluorogen to the cell suspension prior to the cytometry analysis, 
reducing the overall workflow to a single injection step. The ability to quantify both the surface display level and the total expression level enables to evaluate whether low surface expression results from changes in gene expression, protein synthesis, trafficking or degradation. We showed that our approach was well suited to evaluate the ability of small molecules to rescue trafficking defects by flow cytometry, opening great prospects for the design of high throughput screening assays for the discovery of drugs to treat trafficking related diseases.

\section{SUPPORTING INFORMATION}

Supporting information contains Movie S1, Figures S1-S4, SI Text 1, Materials \& Methods.

\section{NOTES}

The authors declare the following competing financial interests: A.G. and L.J. are cofounders and holds equity in Twinkle Bioscience, a company commercializing the FAST technology; A.G., L. J., C. L. and F. P. filed a patent application on the membrane-impermeant fluorogens described in this paper.

\section{ACKNOWLEDGEMENTS}

This work has been supported by the European Research Council (ERC-2016-CoG724705 FLUOSWITCH), the Agence National de la Recherche (ANR-14-CE09-000201), a PhD grant (C. L.) from Region lle-de-France in the framework of DIM NanoK, France Biolmaging (ANR-10-INBS-04), the Fondation Bettencourt Schueller, the Equipex Morphoscope 2 (ANR-11-EQPX-0029) and the program «Investissements 
d'Avenir " launched by the French Government and implemented by ANR (ANR-10IDEX-0001-02 PSL, project Superline).

\section{REFERENCES}

(1) Komatsu, T., Johnsson, K., Okuno, H., Bito, H., Inoue, T., Nagano, T., and Urano, Y. (2011) Real-time measurements of protein dynamics using fluorescence activation-coupled protein labeling method. J. Am. Chem. Soc. 133, 6745-6751.

(2) Sun, X., Zhang, A., Baker, B., Sun, L., Howard, A., Buswell, J., Maurel, D., Masharina, A., Johnsson, K., Noren, C. J., Xu, M.-Q., and Corrêa, I. R., Jr. (2011) Development of SNAP-Tag Fluorogenic Probes for Wash-Free Fluorescence Imaging. Chembiochem 12, 2217-2226.

(3) Prifti, E., Reymond, L., Umebayashi, M., Hovius, R., Riezman, H., and Johnsson, K. (2014) A Fluorogenic Probe for SNAP-Tagged Plasma Membrane Proteins Based on the Solvatochromic Molecule Nile Red. ACS Chem Biol 9, 606-612.

(4) Hirayama, S., Hori, Y., Benedek, Z., Suzuki, T., and Kikuchi, K. (2016)

Fluorogenic probes reveal a role of GLUT4 N-glycosylation in intracellular trafficking. Nat Chem Biol 12, 853-859.

(5) Szent-Gyorgyi, C., Schmidt, B. A., Creeger, Y., Fisher, G. W., Zakel, K. L., Adler, S., Fitzpatrick, J. A. J., Woolford, C. A., Yan, Q., Vasilev, K. V., Berget, P. B., Bruchez, M. P., Jarvik, J. W., and Waggoner, A. (2008) Fluorogen-activating singlechain antibodies for imaging cell surface proteins. Nat Biotechnol 26, 235-240.

(6) Yan, Q., Schmidt, B. F., Perkins, L. A., Naganbabu, M., Saurabh, S., Andreko, S. K., and Bruchez, M. P. (2015) Near-instant surface-selective fluorogenic protein quantification using sulfonated triarylmethane dyes and fluorogen activating proteins. Org Biomol Chem 13, 2078-2086.

(7) Holleran, J., Brown, D., Fuhrman, M. H., Adler, S. A., Fisher, G. W., and Jarvik, J. W. (2010) Fluorogen-activating proteins as biosensors of cell-surface proteins in living cells. Cytometry $A$ 77, 776-782.

(8) Fisher, G. W., Adler, S. A., Fuhrman, M. H., Waggoner, A. S., Bruchez, M. P., and Jarvik, J. W. (2010) Detection and Quantification of 2AR Internalization in Living Cells Using FAP-Based Biosensor Technology. J Biomol Screen 15, 703-709.

(9) Wu, Y., Tapia, P. H., Fisher, G. W., Simons, P. C., Strouse, J. J., Foutz, T., Waggoner, A. S., Jarvik, J., and Sklar, L. A. (2012) Discovery of Regulators of Receptor Internalization with High-Throughput Flow Cytometry. Mol Pharmacol 82, 645-657.

(10) Pratt, C. P., He, J., Wang, Y., Barth, A. L., and Bruchez, M. P. (2015)

Fluorogenic Green-Inside Red-Outside (GIRO) Labeling Approach Reveals Adenylyl Cyclase-Dependent Control of BKa Surface Expression. Bioconjug Chem 26, 19631971.

(11) Snyder, J. C., Pack, T. F., Rochelle, L. K., Chakraborty, S. K., Zhang, M., Eaton, A. W., Bai, Y., Ernst, L. A., Barak, L. S., Waggoner, A. S., and Caron, M. G. (2015) A rapid and affordable screening platform for membrane protein trafficking. BMC Biol $13,107$. 
(12) Naganbabu, M., Perkins, L. A., Wang, Y., Kurish, J., Schmidt, B. F., and Bruchez, M. P. (2016) Multiexcitation Fluorogenic Labeling of Surface, Intracellular, and Total Protein Pools in Living Cells. Bioconjug Chem 27, 1525-1531.

(13) Plamont, M.-A., Billon-Denis, E., Maurin, S., Gauron, C., Pimenta, F. M., Specht, C. G., Shi, J., Querard, J., Pan, B., Rossignol, J., Moncoq, K., Morellet, N., Volovitch, M., Lescop, E., Chen, Y., Triller, A., Vriz, S., Le Saux, T., Jullien, L., and Gautier, A. (2016) Small fluorescence-activating and absorption-shifting tag for tunable protein imaging in vivo. Proc Natl Acad Sci USA 113, 497-502.

(14) Li, C., Plamont, M.-A., Sladitschek, H. L., Rodrigues, V., Aujard, I., Neveu, P., Le Saux, T., Jullien, L., and Gautier, A. (2017) Dynamic multicolor protein labeling in living cells. Chem Sci 8, 5598-5605.

(15) Misumi, Y., Miki, K., Takatsuki, A., Tamura, G., and Ikehara, Y. (1986) Novel blockade by brefeldin A of intracellular transport of secretory proteins in cultured rat hepatocytes. J Biol Chem 261, 11398-11403.

(16) Young, C. W., Robinson, P. F., and Sacktor, B. (1963) Inhibition of the synthesis of protein in intact animals by acetoxycycloheximide and a metabolic derangement concomitant with this blockade. Biochemical Pharmacology 12, 855-865.

(17) Hung, M. C., and Link, W. (2011) Protein localization in disease and therapy. J Cell Sci 124, 3381-3392.

(18) Chia, P. Z. C., Ramdzan, Y. M., Houghton, F. J., Hatters, D. M., and Gleeson, P. A. (2014) High-Throughput Quantitation of Intracellular Trafficking and Organelle Disruption by Flow Cytometry. Traffic 15, 572-582.

(19) Barak, L. S., Oakley, R. H., Laporte, S. A., and Caron, M. G. (2001) Constitutive arrestin-mediated desensitization of a human vasopressin receptor mutant associated with nephrogenic diabetes insipidus. Proc Natl Acad Sci USA 98, 93-98. (20) Wilbanks, A. M., Laporte, S. A., Bohn, L. M., Barak, L. S., and Caron, M. G. (2002) Apparent Loss-of-Function Mutant GPCRs Revealed as Constitutively Desensitized Receptors. Biochemistry 41, 11981-11989.

(21) Morello, J.-P., Salahpour, A., Laperrière, A., Bernier, V., Arthus, M.-F., Lonergan, M., Petäjä-Repo, U., Angers, S., Morin, D., Bichet, D. G., and Bouvier, M. (2000) Pharmacological chaperones rescue cell-surface expression and function of misfolded V2 vasopressin receptor mutants. J. Clin. Invest. 105, 887-895.

TOC

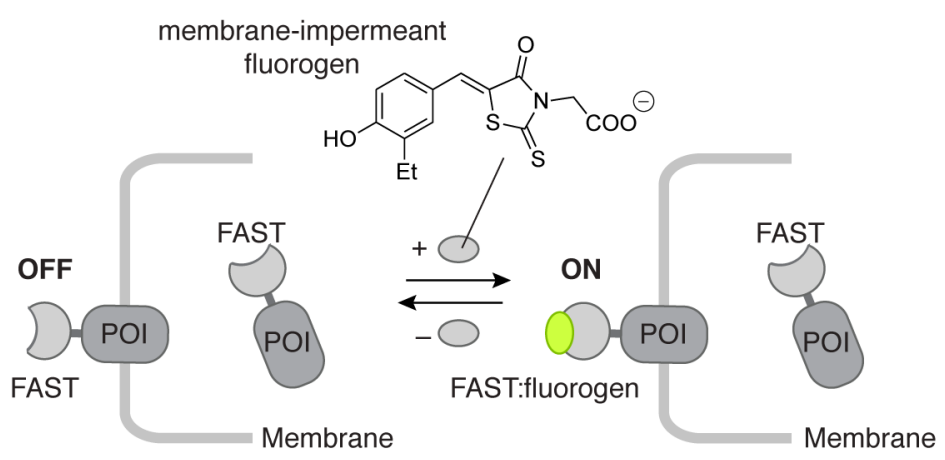




\section{SUPPORTING INFORMATION}

\section{Fluorogenic probing of membrane protein trafficking}

Chenge $\mathrm{Li}^{1}$, Aurélien Mourton ${ }^{2,3}$, Marie-Aude Plamont ${ }^{1}$, Vanessa Rodrigues ${ }^{1}$, Isabelle Aujard ${ }^{1}$, Michel Volovitch ${ }^{2,4}$, Thomas Le Saux ${ }^{1}$, Franck Perez ${ }^{5}$, Sophie Vriz ${ }^{2,6}$, Ludovic Jullien ${ }^{1}$, Alain Joliot $^{2} \&$ Arnaud Gautier ${ }^{1, *}$

1 PASTEUR, Département de Chimie, École Normale Supérieure, PSL University, Sorbonne Université, CNRS, 75005 Paris, France.

2 Center for Interdisciplinary Research in Biology (CIRB), Collège de France, CNRS, INSERM, PSL Research University, Paris, France

${ }^{3}$ PSL Research University, Paris, France

${ }^{4}$ École Normale Supérieure, PSL Research University, Department of biology, Paris, France

${ }^{5}$ Institut Curie, PSL Research University, CNRS UMR144, 26 rue d'Ulm, 75248 Paris Cedex 05, France

${ }^{6}$ Université Paris Diderot, Sorbonne Paris Cité, Biology Department - 75205 Paris Cedex 13 - France

*Correspondence should be addressed to: arnaud.gautier@ens.fr

\section{Content}

Legend of the Movie S1

SI Figures: Fig. S1-S4

SI Text 1

Materials \& Methods

NMR spectra of new compounds

SI References 


\section{Legend of the Movie S1}

Movie S1. Time-lapse of the labeling of FAST-tagged cell-surface proteins. Labeling of a cell expressing sFASTtm 1 with $5 \mu \mathrm{M}$ of HBRAA-3E. HBRAA-3E was added at $\mathrm{t}=0 \mathrm{~s}$. Scale bar is $10 \mu \mathrm{m}$. 


\section{Supplemental Figures}

A
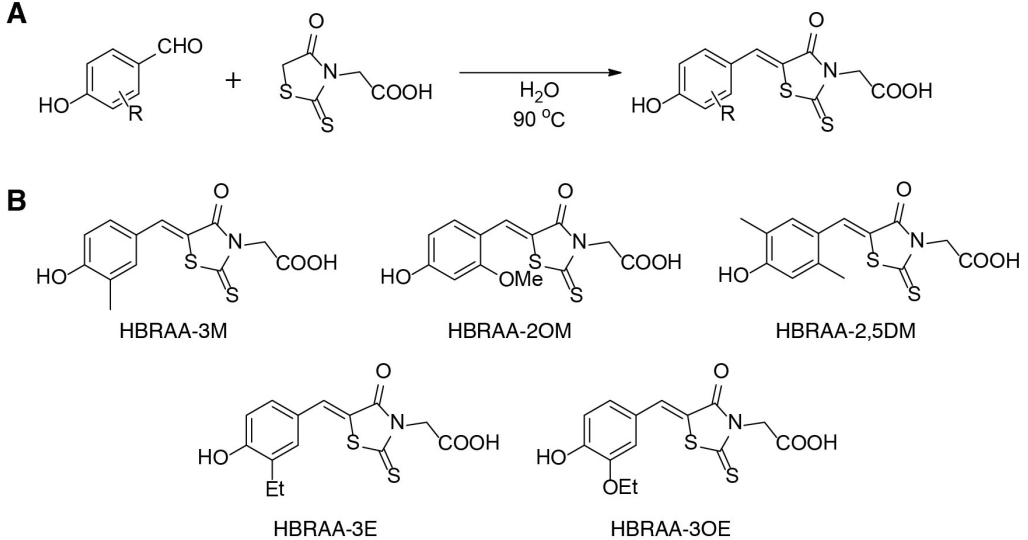

Figure S1. Synthesis. (A) Membrane-impermeant HBR analogs were obtained by condensing substituted 4-hydroxy-benzaldehyde derivatives with rhodanine acetic acid in water at $90^{\circ} \mathrm{C}$. (B) Chemical structures and names of the membrane-impermeant HBR analogs synthesized in this study. 

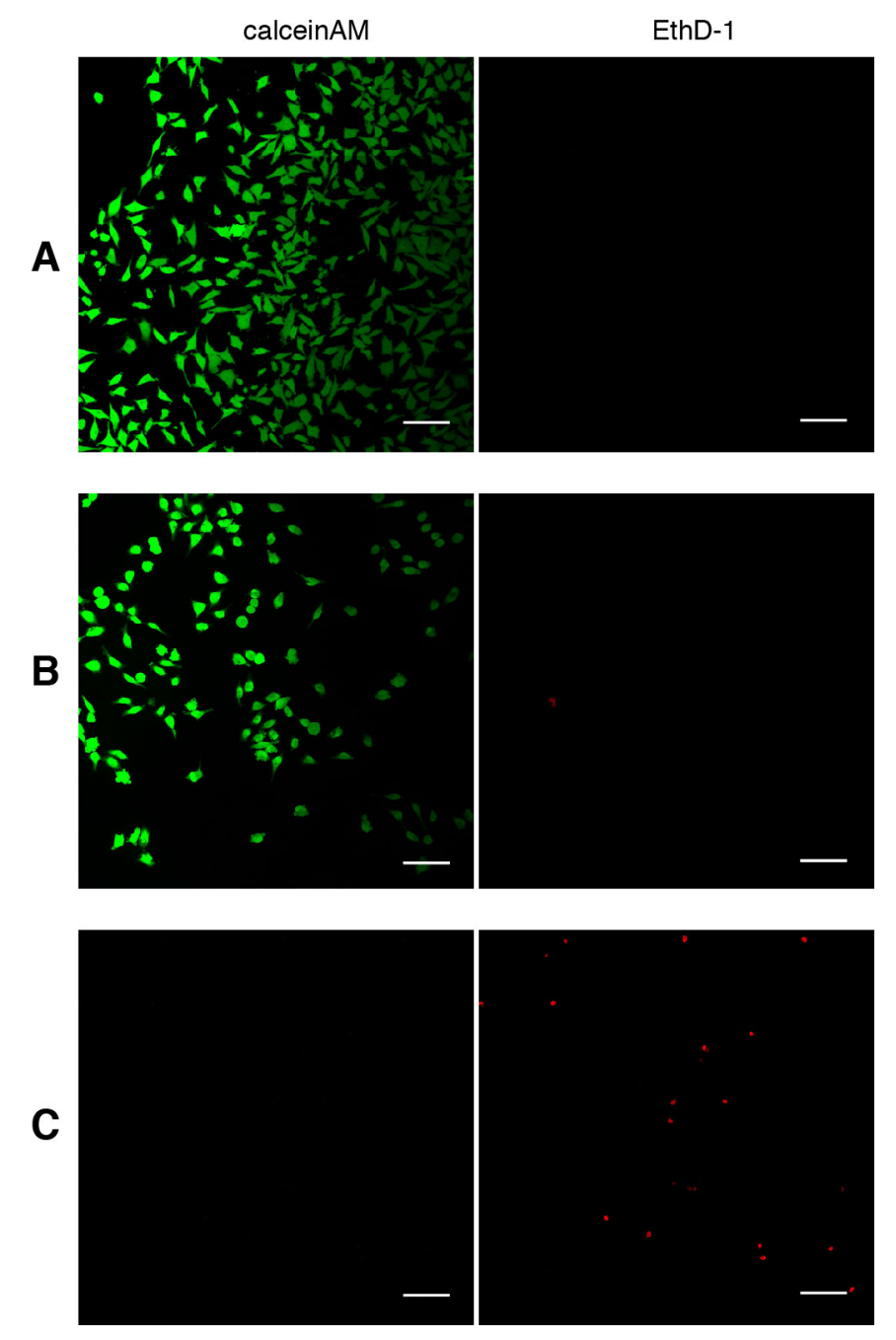

Figure S2. Viability assay. (A) HeLa cells were incubated for $24 \mathrm{~h}$ with solutions of HBRAA-3E at $5 \mu \mathrm{M}$. Cell viability was tested by using calceinAM and EthD1 (LIVE/DEAD® viability/cytotoxicity assay kit). CalceinAM is a cell-permeant profluorophore cleaved by intracellular esterases releasing the green fluorescent polyanionic calcein in live cells. EthD1 (Ethidium homodimer 1) is a non cell-permeant nucleic acid red fluorescent stain that enters only cells with damaged membranes and undergoes a fluorescence enhancement upon binding to nucleic acids, thereby producing a bright red fluorescence in dead cells. (B) Live control: HeLa cells incubated with no dye. (C) Dead control: HeLa cells incubated for $30 \mathrm{~min}$ with $1 \%$ hydrogen peroxide. Cell fluorescence was evaluated by confocal microscopy. The experiment shows that HBRAA-3E is non-toxic for HeLa cells at the concentrations used for imaging. (A-C) Scale bars $100 \mu \mathrm{m}$. 
A
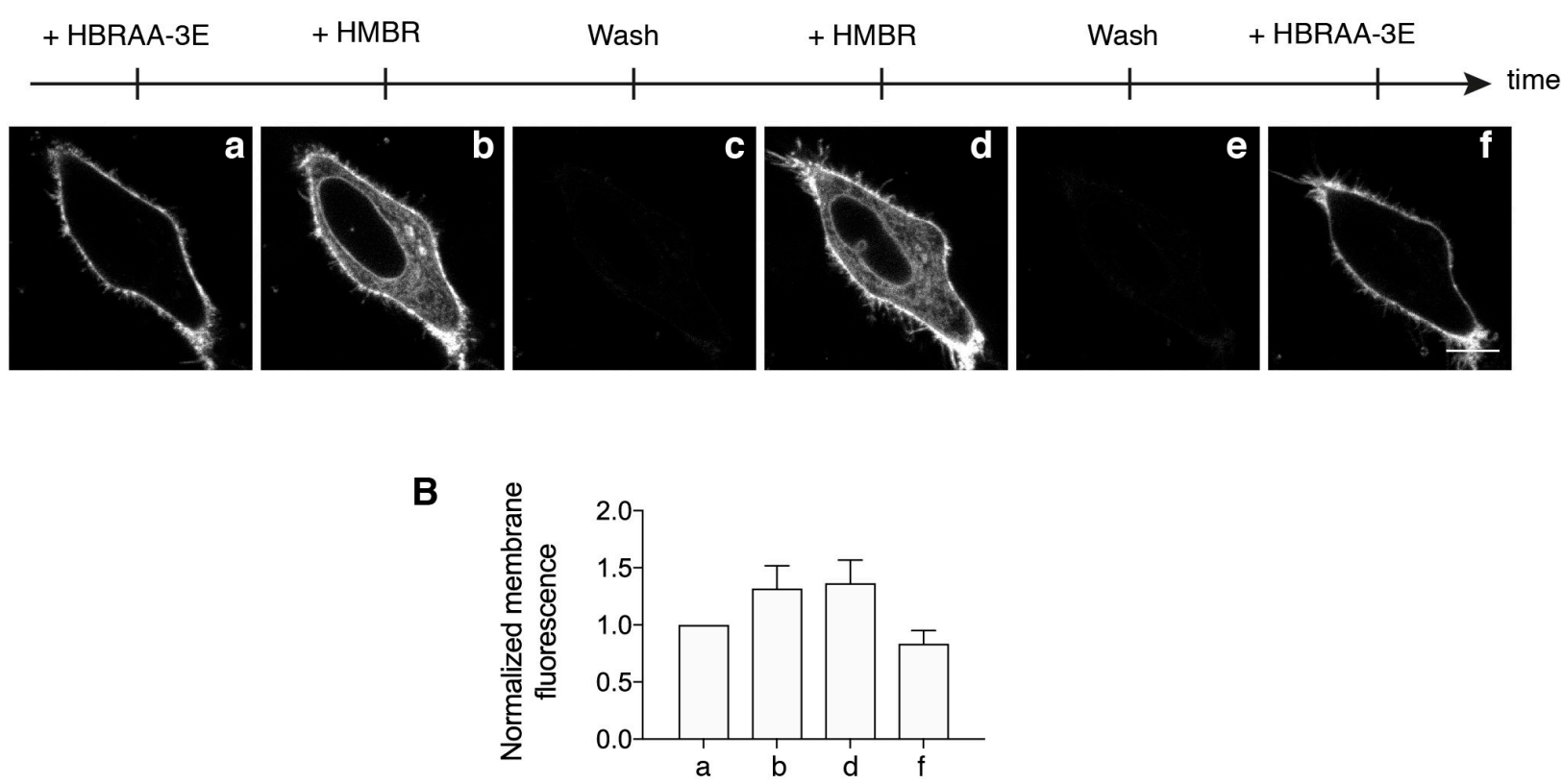

Figure S3. HMBR can replace HBRAA-3E dynamically. (A) HeLa cells expressing sFASTtm1 were treated with $5 \mu \mathrm{M}$ HBRAA-3E and imaged immediately (a). After removal of the HBRAA-3E-containing medium, cells were treated with $5 \mu \mathrm{M}$ HMBR and imaged immediately (b). To unlabel FAST, cells were washed three times with PBS, and then imaged immediately to verify unlabeling (c). Unlabeled cells were then treated with $5 \mu \mathrm{M}$ HMBR and imaged immediately (d). Cells were then washed again three times with PBS (e), and then treated with $5 \mu \mathrm{M}$ HBRAA-3E to show that the fluorescence level was identical to that observed at the beginning of the experiment (f). All images were recorded using identical settings. Ex/Em 488/493-575 nm. Scale bar is $10 \mu \mathrm{m}$. (B) Quantification of membrane fluorescence ( $n=3$ experiments). For each experiment, fluorescence levels were normalized using the intensity level measured after the first labeling with HBRAA-3E (condition a). 
wt D2R

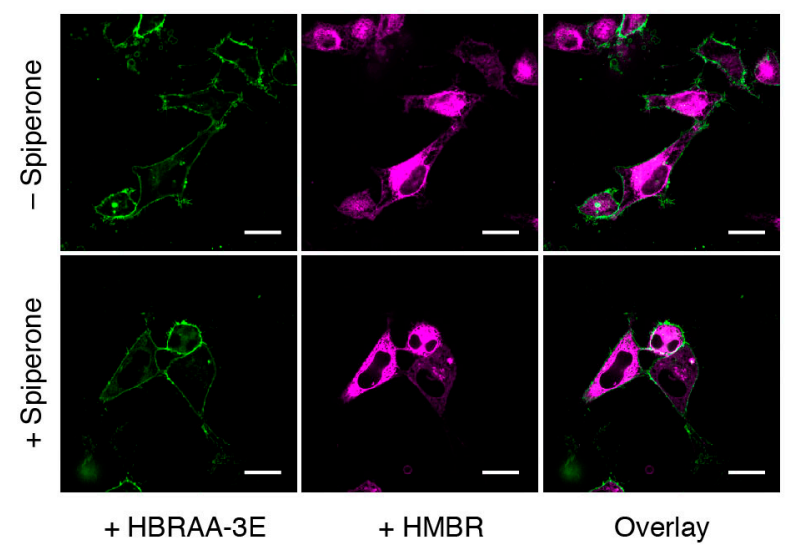

mut D2R

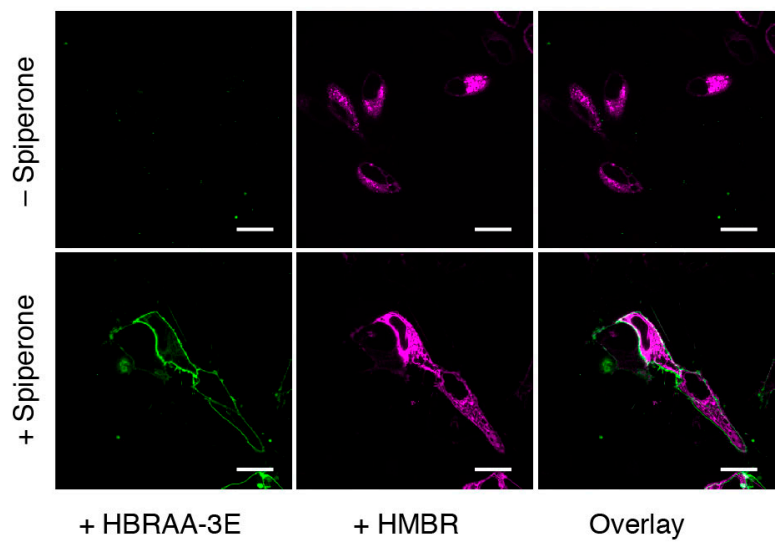

Figure S4. HeLa cells expressing wild-type Dopamine Receptor D2 (wt D2R) or its defective mutant (mut D2R) fused to FAST were treated for $24 \mathrm{~h}$ without or with $10 \mu \mathrm{M}$ Spiperone. Live cells were analyzed by fluorescent microscopy after sequential addition of $15 \mu \mathrm{M}$ of membrane impermeant HBRAA-3E (green) followed by $5 \mu \mathrm{M}$ of membranepermeant HMBR (magenta). Scale bars $20 \mu \mathrm{m}$. 


\section{SI Text 1: Quantification of cell surface protein level by flow cytometry}

For a given fluorogen $i$, the fluorescence intensity $I_{F, i}$ per cell is proportional to the protein level $\mathrm{n}$, the fluorescence quantum yield $\phi_{\mathrm{F}, i}$ of the FAST:fluorogen complex, and the fraction $\alpha_{F, i}$ of bound fluorogen

$$
I_{\mathrm{F}, i} \propto \mathrm{n} \times \phi \mathrm{F}, i \times \alpha_{\mathrm{F}, i}
$$

Accordingly, for cells treated with the membrane-impermeant fluorogen HBRAA-3E,

$$
I_{\text {F,HBRAA-3E }} \propto \mathrm{n}_{\text {Surface }} \times \phi \text { F,HBRAA-3E } \times \alpha_{F, \text { HBRAA-3E }}
$$

where $\mathrm{n}_{\text {surface }}$ is the surface protein level.

For cells treated with the membrane-permeant fluorogen HMBR,

$$
I_{\mathrm{F}, \mathrm{HMBR}} \propto \mathrm{n}_{\text {Total }} \times \phi \mathrm{F}, \mathrm{HMBR} \times \alpha_{\mathrm{F}, \mathrm{HMBR}}
$$

where $\mathrm{n}_{\text {Total }}$ is the total protein level.

Using a control experiment (Ctrl) to normalize, we can directly extract a normalized cell-surface protein level:

$$
\mathrm{n}_{\text {Surface, norm }}=\mathrm{n}_{\text {Surface }} / \mathrm{n}_{\text {Surface,Ctrl }}=I_{\mathrm{F}, \mathrm{HBRAA}-3 \mathrm{E}} / I_{\mathrm{F}, \mathrm{HBRAA}-3 \mathrm{E}, \mathrm{Ctrl}}
$$

and a normalized total protein level:

$$
\mathrm{n}_{\text {Total, norm }}=\mathrm{n}_{\text {Total }} / \mathrm{n}_{\text {Total, }} \text { trl }=I_{\mathrm{F}, \mathrm{HMBR}} / I_{\mathrm{F}, \mathrm{HMBR}, \mathrm{Ctrl}}
$$




\section{Materials \& Methods}

Chemical synthesis - general information Commercially available reagents were used as starting materials without further purification. NMR spectra were recorded on a $\mathrm{AC}$ Bruker spectrometer at $300 \mathrm{MHz}$ for ${ }^{1} \mathrm{H}$ and $75 \mathrm{MHz}$ for ${ }^{13} \mathrm{C}$; chemical shifts are reported in ppm with protonated solvent as internal reference ${ }^{1} \mathrm{H}, \mathrm{CHCl}_{3}$ in $\mathrm{CDCl}_{3}$ 7.26 ppm, $\mathrm{CHD}_{2} \mathrm{SOCD}_{3}$ in $\mathrm{CD}_{3} \mathrm{SOCD}_{3} 2.50 \mathrm{ppm} ;{ }^{13} \mathrm{C},{ }^{13} \mathrm{CDCl}_{3}$ in $\mathrm{CDCl}_{3} 77.0 \mathrm{ppm}$, ${ }^{13} \mathrm{CD}_{3} \mathrm{SOCD}_{3}$ in $\mathrm{CD}_{3} \mathrm{SOCD}_{3} 39.52$ ppm; coupling constants $J$ are given in $\mathrm{Hz}$. Mass spectra (chemical ionization or high resolution) were performed by the Service de Spectrométrie de Masse de Chimie ParisTech and the Institut de Chimie Organique et Analytique de l'Université d'Orléans. Column chromatography was performed on silica gel 60 (0.040-0.063 nm) Merck. Analytical thin-layer chromatography (TLC) was conducted on Merck silica gel 60 F254 precoated plates. The substituted hydroxybenzaldehyde derivatives were obtained from Sigma, with the exception of the 4-hydroxy-3-ethylbenzaldehyde, which was synthesized according to previous report ${ }^{1}$.

General protocol for the synthesis of the membrane-impermeant fluorogens A solution containing rhodanine-3-acetic acid (191 $\mathrm{mg}, 1.0 \mathrm{mmol})$ and the substituted 4-hydroxy-benzaldehyde $(1.0 \mathrm{mmol})$ in $40 \mathrm{~mL}$ of water was stirred at $90^{\circ} \mathrm{C}$ for 7 days. After cooling to $4^{\circ} \mathrm{C}$ and standing overnight, the precipitate was filtered through a glass filter and the crude solid was washed with water, ethanol and dried over $\mathrm{P}_{2} \mathrm{O}_{5}$, to give the desired product.

\section{(Z)-2-(5-(4-hydroxy-3-methylbenzylidene)-4-oxo-2-thioxothiazolidin-3-yl)acetic acid (HBRAA-3M)}

Yellow powder (80 \%). ${ }^{1} \mathrm{H}$ NMR (300 MHz, $\mathrm{CD}_{3} \mathrm{SOCD}_{3}, \delta$ in ppm): 10.50 (s, 1H), 7.74 (s, 1H), $7.40(\mathrm{~s}, 1 \mathrm{H}), 7.38(\mathrm{~d}, J=8.1 \mathrm{~Hz}, 1 \mathrm{H}), 6.96(\mathrm{~d}, J=8.1 \mathrm{~Hz}, 1 \mathrm{H}), 4.72(\mathrm{~s}, 2 \mathrm{H})$, 2.18 (s, 3H); ${ }^{13} \mathrm{C}$ NMR (75 MHz, $\mathrm{CD}_{3} \mathrm{SOCD}_{3}, \delta$ in ppm): 193.2, 167.4, 166.5, 159.3, $134.9,134.1,131.1,125.7,123.8,116.8,115.8,45.0,15.9 ; \mathrm{MS}$ (ESI): m/z 308.2[M$\mathrm{H}]^{-}$, calcd mass for $\left[\mathrm{C}_{13} \mathrm{H}_{10} \mathrm{NO}_{4} \mathrm{~S}_{2}\right]^{-:}$308.0; HRMS (ESI): m/z $310.0202[\mathrm{M}+\mathrm{H}]^{+}$, calcd mass for $\left[\mathrm{C}_{13} \mathrm{H}_{12} \mathrm{NO}_{4} \mathrm{~S}_{2}\right]^{+:} 310.0208$. 
(Z)-2-(5-(4-hydroxy-2-methoxybenzylidene)-4-oxo-2-thioxothiazolidin-3-yl)acetic acid (HBRAA-2OM)

Orange powder (74\%). ${ }^{1} \mathrm{H}$ NMR (300 MHz, $\mathrm{CD}_{3} \mathrm{SOCD}_{3}, \delta$ in ppm): $13.40(\mathrm{~s}, 1 \mathrm{H})$, $10.72(\mathrm{~s}, 1 \mathrm{H}), 7.92(\mathrm{~s}, 1 \mathrm{H}), 7.33(\mathrm{~d}, J=8.7 \mathrm{~Hz}, 1 \mathrm{H}), 6.57(\mathrm{dd}, J=8.4,2.1 \mathrm{~Hz}, 1 \mathrm{H})$, $6.53(\mathrm{~d}, J=2.1 \mathrm{~Hz}, 1 \mathrm{H}), 4.71(\mathrm{~s}, 2 \mathrm{H}), 3.87(\mathrm{~s}, 3 \mathrm{H}) ;{ }^{13} \mathrm{C} \mathrm{NMR}\left(75 \mathrm{MHz}, \mathrm{CD}_{3} \mathrm{SOCD}_{3}, \delta\right.$ in ppm): 193.6, 167.4, 166.7, 163.4, 160.6, 132.6, 129.9, 116.6, 112.8, 109.2, 99.4, 55.7, 45.0; MS (ESI): m/z 324.2[M-H]', calcd mass for [ $\left.\mathrm{C}_{13} \mathrm{H}_{10} \mathrm{NO}_{5} \mathrm{~S}_{2}\right]:$ : 324.0; HRMS (ESI): $\mathrm{m} / \mathrm{z} 324.0007[\mathrm{M}-\mathrm{H}]^{-}$, calcd mass for $\left[\mathrm{C}_{13} \mathrm{H}_{10} \mathrm{NO}_{5} \mathrm{~S}_{2}\right]: 324.0000$.

(Z)-2-(5-(4-hydroxy-2, 5-dimethylbenzylidene)-4-oxo-2-thioxothiazolidin-3yl)acetic acid (HBRAA-2,5DM)

Orange powder (59 \%). ${ }^{1} \mathrm{H}$ NMR (300 MHz, $\mathrm{CD}_{3} \mathrm{SOCD}_{3}, \delta$ in ppm): $13.43(\mathrm{~s}, 1 \mathrm{H})$, $10.36(\mathrm{~s}, 1 \mathrm{H}), 7.86(\mathrm{~s}, 1 \mathrm{H}), 7.17(\mathrm{~s}, 1 \mathrm{H}), 6.77(\mathrm{~s}, 1 \mathrm{H}), 4.72(\mathrm{~s}, 2 \mathrm{H}), 2.36(\mathrm{~s}, 3 \mathrm{H}), 2.15$ (s, 3H); ${ }^{13} \mathrm{C}$ NMR $\left(75 \mathrm{MHz}, \mathrm{CD}_{3} \mathrm{SOCD}_{3}, \delta\right.$ in ppm): 193.5, 167.4, 166.4, 159.0, 140.2, $131.8,130.9,123.3,122.4,117.8,117.4,44.9,19.2,15.6 ; \mathrm{MS}$ (ESI): $\mathrm{m} / \mathrm{z} 322.2$ [M$\mathrm{H}]^{-}$, calcd mass for $\left[\mathrm{C}_{14} \mathrm{H}_{12} \mathrm{NO}_{4} \mathrm{~S}_{2}\right]$ ]: 322.0; HRMS (ESI): m/z 322.0214 [M-H]', calcd mass for $\left[\mathrm{C}_{14} \mathrm{H}_{12} \mathrm{NO}_{4} \mathrm{~S}_{2}\right]: 322.0208$.

\section{(Z)-2-(5-(4-hydroxy-3-ethylbenzylidene)-4-oxo-2-thioxothiazolidin-3-yl)acetic} acid (HBRAA-3E)

Yellow powder (62 \%). ${ }^{1} \mathrm{H}$ NMR $\left(300 \mathrm{MHz}, \mathrm{CD}_{3} \mathrm{SOCD}_{3}, \delta\right.$ in ppm): $13.44(\mathrm{~s}, 1 \mathrm{H})$, 10.49 (s, 1H), 7.77 (s, 1H), 7.41 (s, 1H), 7.39 (d, J = 7.8 Hz, 1H), 6.97 (d, $J=7.8 \mathrm{~Hz}$, $1 \mathrm{H}$ ), 4.72 (s, 2H), 2.59 (q, $J=7.2 \mathrm{~Hz}, 2 \mathrm{H}), 1.17$ (t, $J=7.2 \mathrm{~Hz}, 3 \mathrm{H}) ;{ }^{13} \mathrm{C} \mathrm{NMR}(75 \mathrm{MHz}$, $\mathrm{CD}_{3} \mathrm{SOCD}_{3}, \delta$ in ppm): 193.1, 167.4, 166.5, 158.9, 135.0, 132.5, 131.5, 131.0, 123.9, 116.8, 116.0, 45.0, 22.5, 13.7; MS (ESI): $\mathrm{m} / \mathrm{z} 322.2[\mathrm{M}-\mathrm{H}]$; calcd mass for $\left[\mathrm{C}_{14} \mathrm{H}_{12} \mathrm{NO}_{4} \mathrm{~S}_{2}\right]:$ :322.0; HRMS (ESI): $\mathrm{m} / \mathrm{z} 322.0212[\mathrm{M}-\mathrm{H}]^{-}$, calcd mass for $\left[\mathrm{C}_{14} \mathrm{H}_{12} \mathrm{NO}_{4} \mathrm{~S}_{2}\right]: 322.0208$.

(Z)-2-(5-(4-hydroxy-3-ethoxybenzylidene)-4-oxo-2-thioxothiazolidin-3-yl)acetic acid (HBRAA-3OE)

Yellow powder (59 \%). ${ }^{1} \mathrm{H}$ NMR (300 MHz, $\mathrm{CD}_{3} \mathrm{SOCD}_{3}, \delta$ in ppm): $13.43(\mathrm{~s}, 1 \mathrm{H})$, $10.13(\mathrm{~s}, 1 \mathrm{H}), 7.79(\mathrm{~s}, 1 \mathrm{H}), 7.20(\mathrm{~s}, 1 \mathrm{H}), 7.16(\mathrm{~d}, J=8.4 \mathrm{~Hz}, 1 \mathrm{H}), 6.97(\mathrm{~d}, J=8.4 \mathrm{~Hz}$, $1 \mathrm{H}), 4.73(\mathrm{~s}, 2 \mathrm{H}), 4.10$ (q, $J=6.9 \mathrm{~Hz}, 2 \mathrm{H}), 1.37$ (t, $J=6.9 \mathrm{~Hz}, 3 \mathrm{H}) ;{ }^{13} \mathrm{C} \mathrm{NMR}(75 \mathrm{MHz}$, 
$\mathrm{CD}_{3} \mathrm{SOCD}_{3}, \delta$ in ppm) : 193.0, 167.3, 166.4, 150.7, 147.3, 135.0, 125.5, 124.3, 117.2, 116.5, 115.7, 64.0, 45.0, 14.6; MS (ESI): $\mathrm{m} / \mathrm{z} 338.3[\mathrm{M}-\mathrm{H}]^{-}$, calcd mass for $\left[\mathrm{C}_{14} \mathrm{H}_{12} \mathrm{NO}_{5} \mathrm{~S}_{2}\right]:$ : 338.0; HRMS (ESI): $\mathrm{m} / \mathrm{z} 338.0162[\mathrm{M}-\mathrm{H}]^{-}$, calcd mass for $\left[\mathrm{C}_{14} \mathrm{H}_{12} \mathrm{NO}_{5} \mathrm{~S}_{2}\right]: 338.0157$.

Molecular biology FAST is a variant of the photoactive yellow protein (PYP) containing the mutations C69G, Y94W, T95M, F96I, D97P, Y98T, Q99S, M100R, T101G. The plasmid pAG96 for cytoplasmic expression of FAST fused to mCherry was previously reported ${ }^{2}$. The plasmid pAG211 for mammalian expression of sFASTtm1, which consists in FAST fused at the $\mathrm{N}$-terminus to the murine Ig $\kappa$-chain leader sequence and at the $\mathrm{C}$-terminus to the platelet derived growth factor receptor (PDGFR) transmembrane domain, was obtained by inserting the sequence coding FAST within the pDisplay plasmid (ThermoFisher) using Sal I and Bgl II restriction sites. SFASTtm2 contains the IL2 leader sequence upstream FAST, and the transmembrane fragment of human CD4 (aa 393-428) downstream. The plasmid pAG299 for the mammalian expression of FAST-D2R was obtained by inserting the sequence coding for FAST-D2R (that also included at the $\mathrm{N}$-terminus the signal sequence MDTSRLGVLLSLPVLLQLATG of the Leucine-rich repeat-containing Gprotein coupled receptor 5 (Lgr5) for secretion) within the pDisplay plasmid (ThermoFisher) using EcoR I and Xho I restriction sites. The plasmid pAG300 for the mammalian expression of FAST-mutD2R (where mutD2R contains the mutations D131A, R132A) was obtained from pAG299 by site-directed mutagenesis. All constructs are available upon request.

Bacterial expression and protein purification FAST protein used for in vitro characterizations was obtained as previously described ${ }^{1}$.

Physical chemistry experiments $\mathrm{pH}$ measurements were performed on a standard pH meter PHM210 Radiometer Analytical (calibrated with aqueous buffers at pH 4 and 7 or 10) with a Crison 5208 Electrode (Barcelona, Spain). UV/Vis absorption spectra were recorded in $1 \mathrm{~cm} \times 1 \mathrm{~cm}$ quartz cuvettes (Hellma) on a diode array UV/Vis spectrophotometer (Evolution array, Thermo Scientific). Corrected fluorescence spectra upon one-photon excitation were recorded with a Photon Technology International QuantaMaster QM-1 spectrofluorimeter (PTI, Monmouth 
Junction, NJ) equipped with a Peltier cell holder (TLC50, Quantum Northwest, Shoreline, WA). The overall emission quantum yields after one-photon excitation were determined as previously described ${ }^{2}$. Affinity constants were determined by spectrofluorometric titration using a Spark $10 \mathrm{M}$ plate reader (Tecan) following protocols previously described ${ }^{2}$.

Mammalian cell culture HeLa cells were cultured in DMEM supplemented with phenol red, Glutamax I, $10 \%$ (vol/vol) fetal calf serum (FCS), and $1 \%$ penicillin-streptomycin at $37{ }^{\circ} \mathrm{C}$ within a $5 \% \mathrm{CO}_{2}$ atmosphere. For microscopic imaging, cells were seeded in $\mu$ Dish or $\mu$ Slide IBIDI (Biovalley) coated with poly-Llysine. Cells were transiently transfected using Genejuice (Merck) or Lipofectamine 2000 (Invitrogen) according to the manufacturer's protocol. Before imaging, cells were washed with PBS, and treated with DMEM media (without serum and phenol red) containing the fluorogens at the indicated concentrations. Cells were imaged directly without washing.

Cell viability assay HeLa cells were treated with DMEM media containing the fluorogens at the indicated concentrations for 24 hours. Cell viability was evaluated by fluorescence microscopy using the LIVE/DEAD ${ }^{\circledR}$ viability/cytotoxicity assay kit (Molecular Probes, Life Technologies) following the manufacter's protocol.

Microscopy Confocal micrographs were acquired on a Zeiss LSM 710 Laser Scanning Microscope equipped with a Plan Apochromat 63X / 1.4 NA oil immersion objective or on a Zeiss Axioobserver Z1 spinning disk microscope equipped with a 100X / 1.4 NA oil immersion objective. Images were analyzed with Image J.

Flow cytometry Cells were seeded at 125,000 cells per well. After 24 hours, cells were transfected and expression was induced with $0.5 \mu \mathrm{g} / \mathrm{ml}$ doxycyline for $24 \mathrm{~h}$. Drugs or appropriate control were added to the culture medium either immediately for overnight treatment (Spiperone $10 \mu \mathrm{M}$, control $=\mathrm{DMSO}$ ) or the next day 6 hours before harvesting (Brefeldine A $1 \mu \mathrm{g} / \mathrm{mL}$, Cycloheximide $15 \mu \mathrm{g} / \mathrm{mL}$, control = DMSO + ethanol). Cells were washed with PBS and harvested using 2mM EDTA in PBS. After 3 minutes centrifugation at $\sim 120 \mathrm{~g}$, cells were resuspended in appropriate 
volume of ice-cold PBS containing a dye to detect cell death (TO-PRO 3, 1:1000, Invitrogen) and kept on ice. Samples were then separated into 2 tubes in which either cell-permeant fluorogen HMBR or cell-impermeant fluorogen HBRAA-3E was added just before cytometry analysis using a FACSCalibur cytometer (BD Biosciences). For the experiments on Figure 3B, the concentrations of HBRAA-3E and HMBR used for labeling were $50 \mu \mathrm{M}$ and $5 \mu \mathrm{M}$, respectively. For the experiments on Figure $3 \mathrm{C}$, the concentrations of HBRAA-3E and HMBR used for labeling were $5 \mu \mathrm{M}$ and $5 \mu \mathrm{M}$, respectively. Acquisition and quantification made use of CELLQuest pro software (BD Biosciences). 
HBRAA-3M

${ }^{1} \mathrm{H}$ NMR spectrum

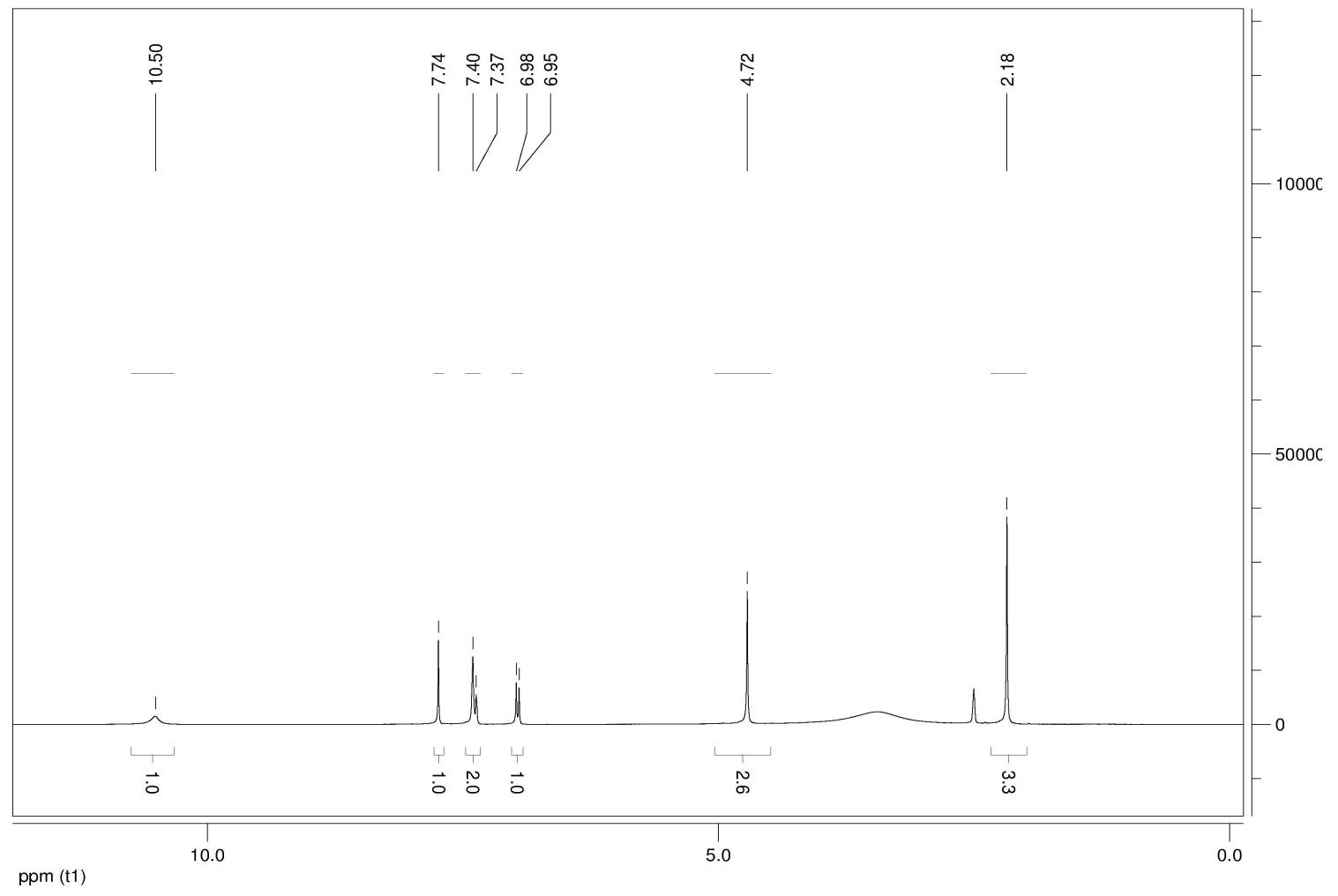

${ }^{13} \mathrm{C}$ NMR spectrum

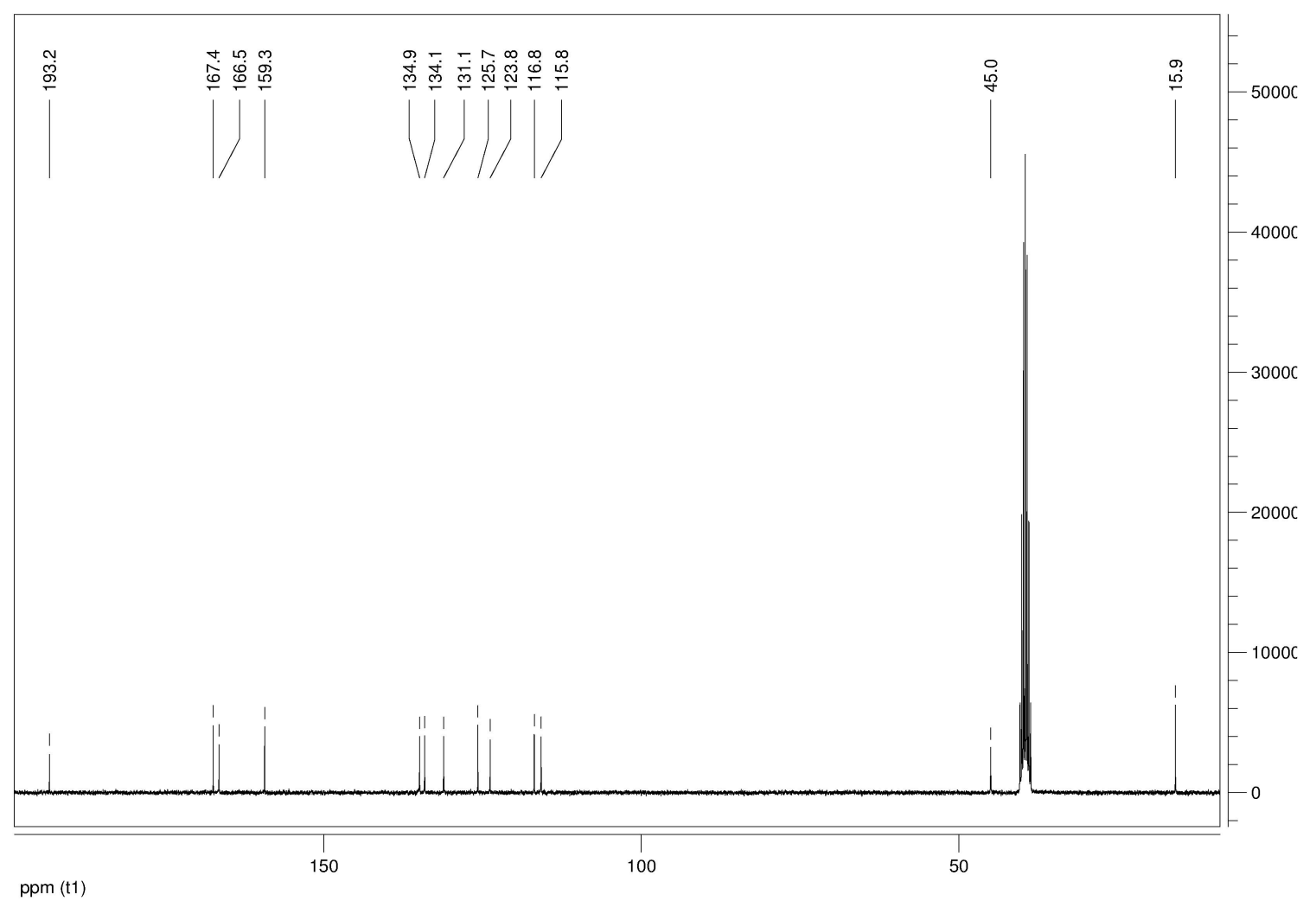


HBRAA-2OM

${ }^{1} \mathrm{H}$ NMR spectrum

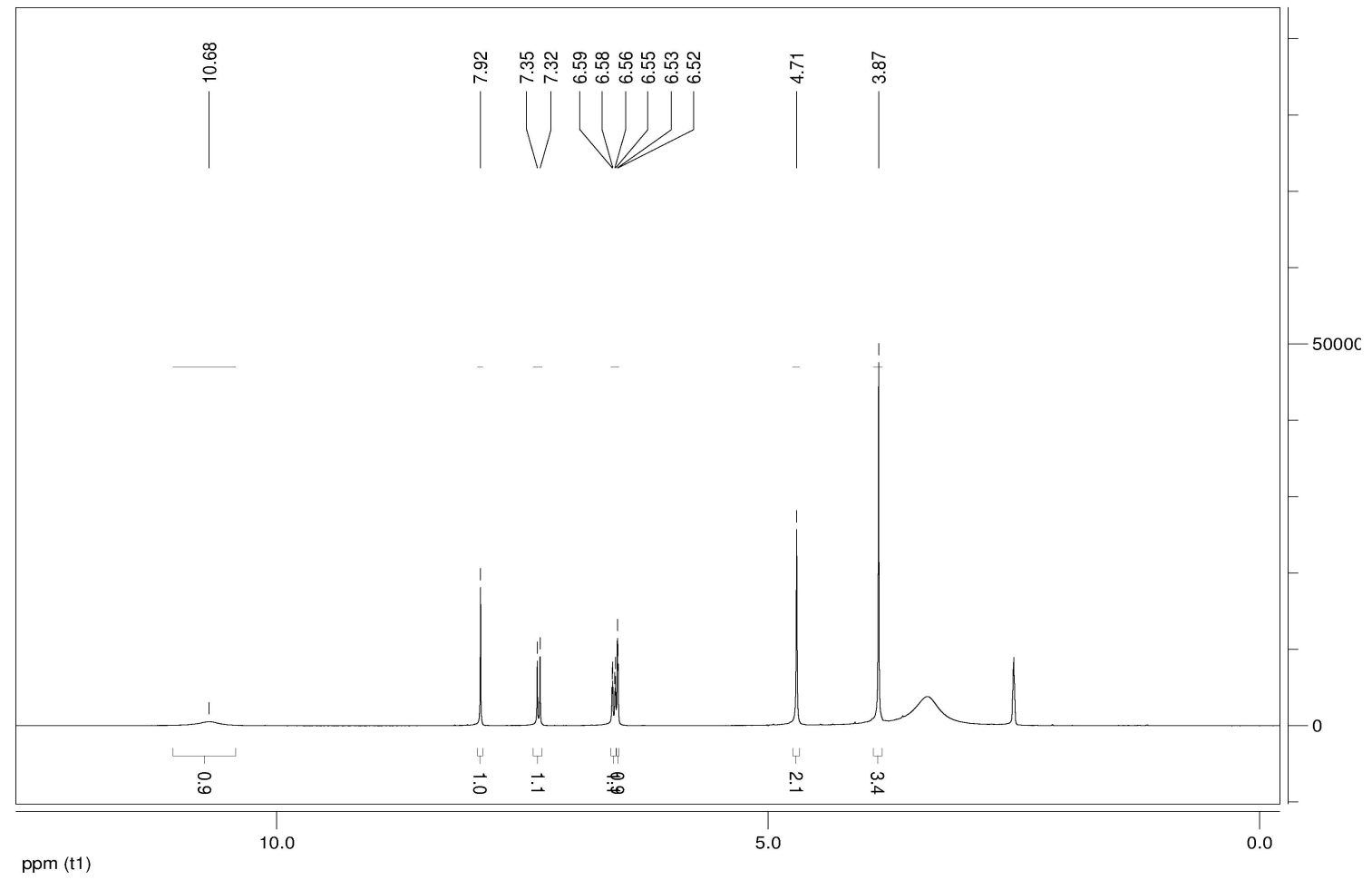

${ }^{13} \mathrm{C}$ NMR spectrum

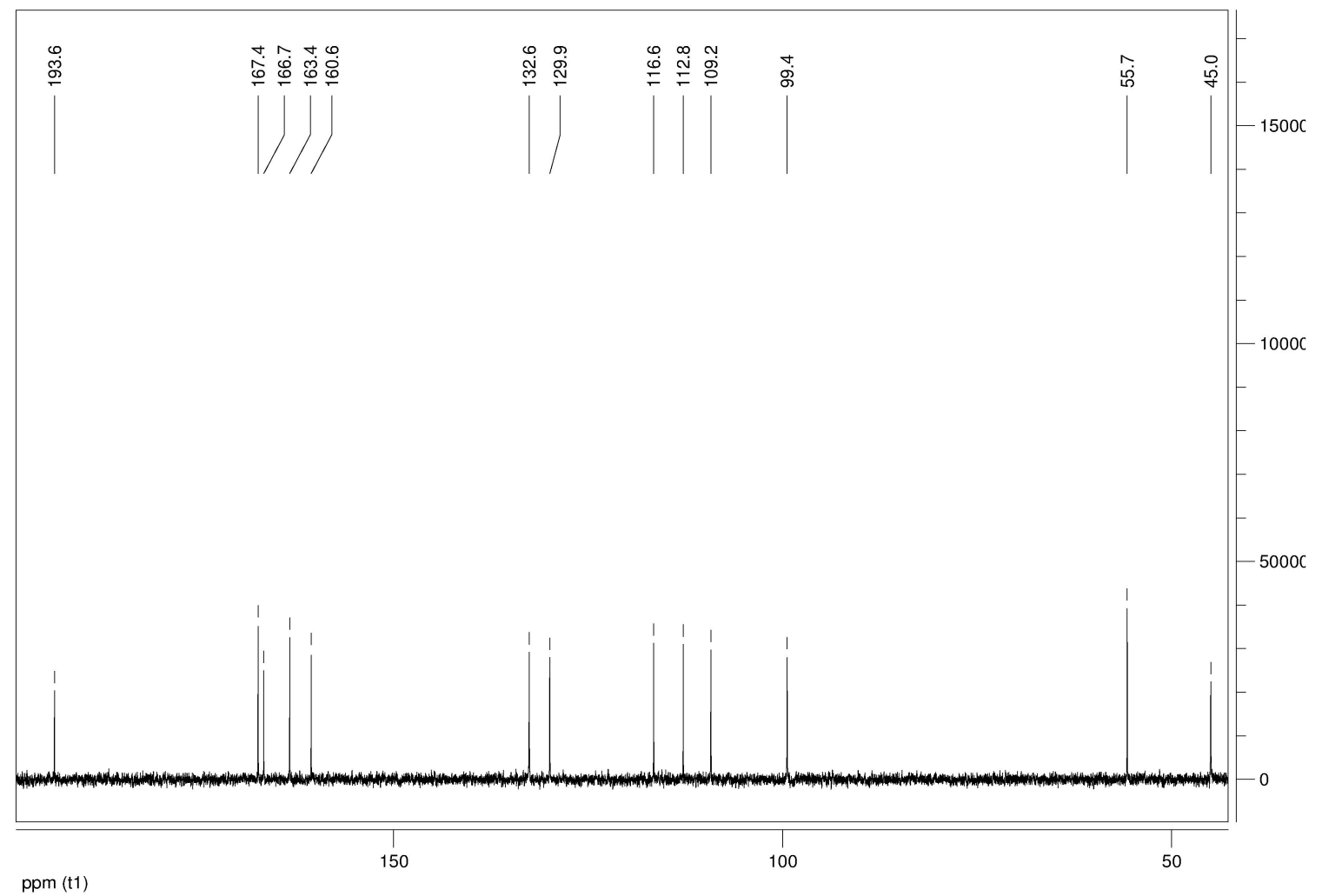


HBRAA-2,5DM

${ }^{1} \mathrm{H}$ NMR spectrum

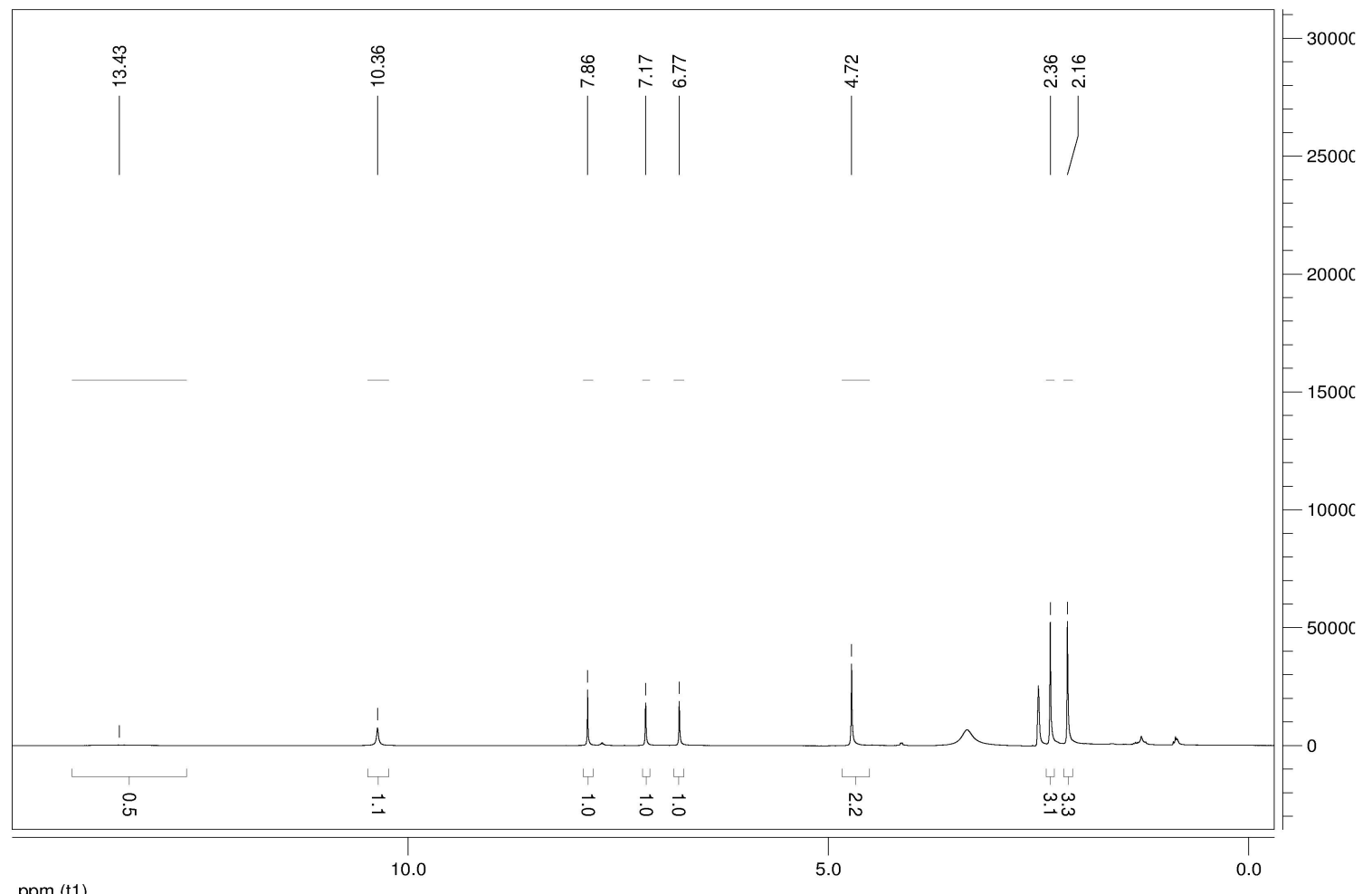

${ }^{13} \mathrm{C}$ NMR spectrum

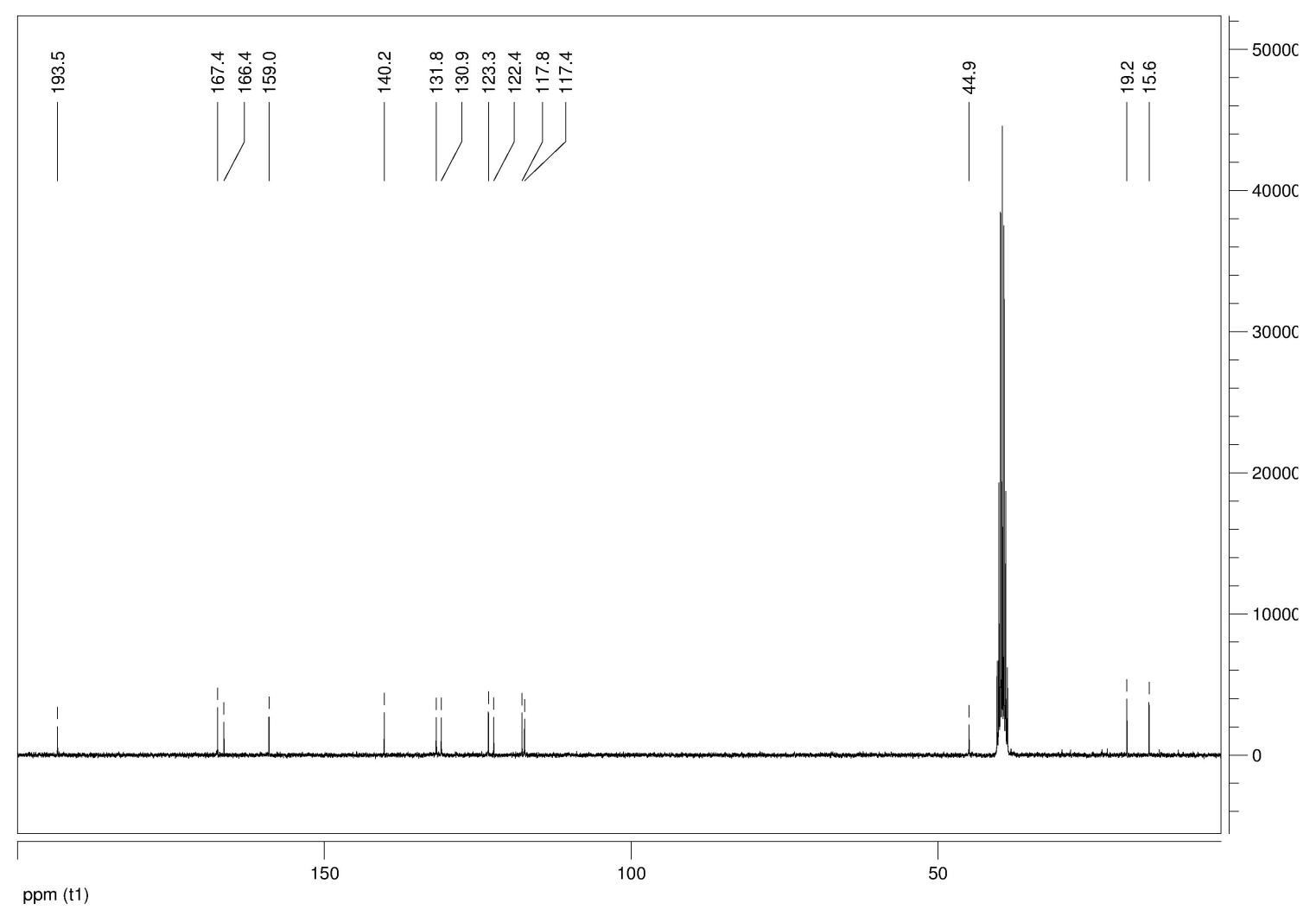


HBRAA-3E

${ }^{1} \mathrm{H}$ NMR spectrum

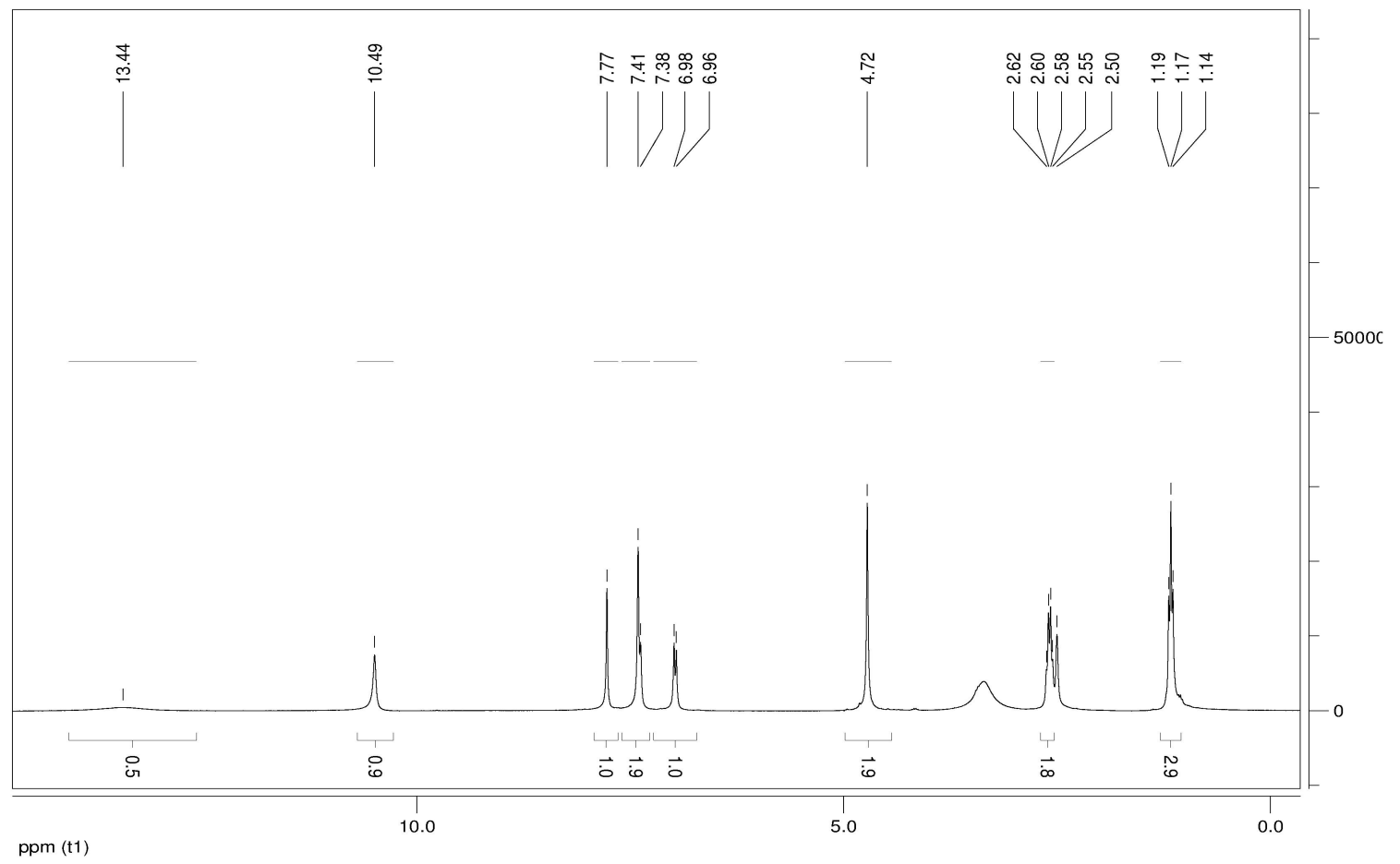

${ }^{13} \mathrm{C}$ NMR spectrum

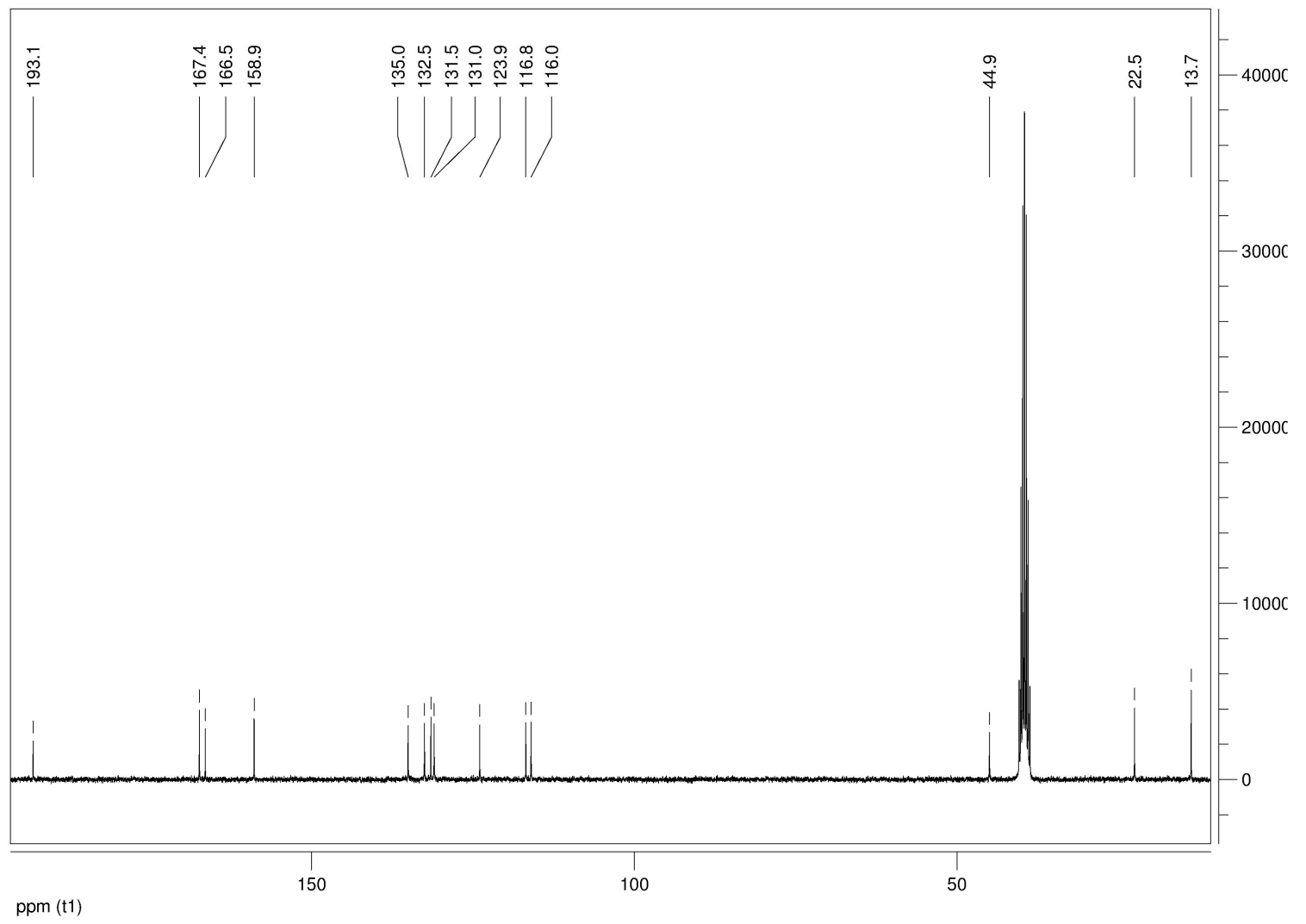


HBRAA-3OE

${ }^{1} \mathrm{H}$ NMR spectrum

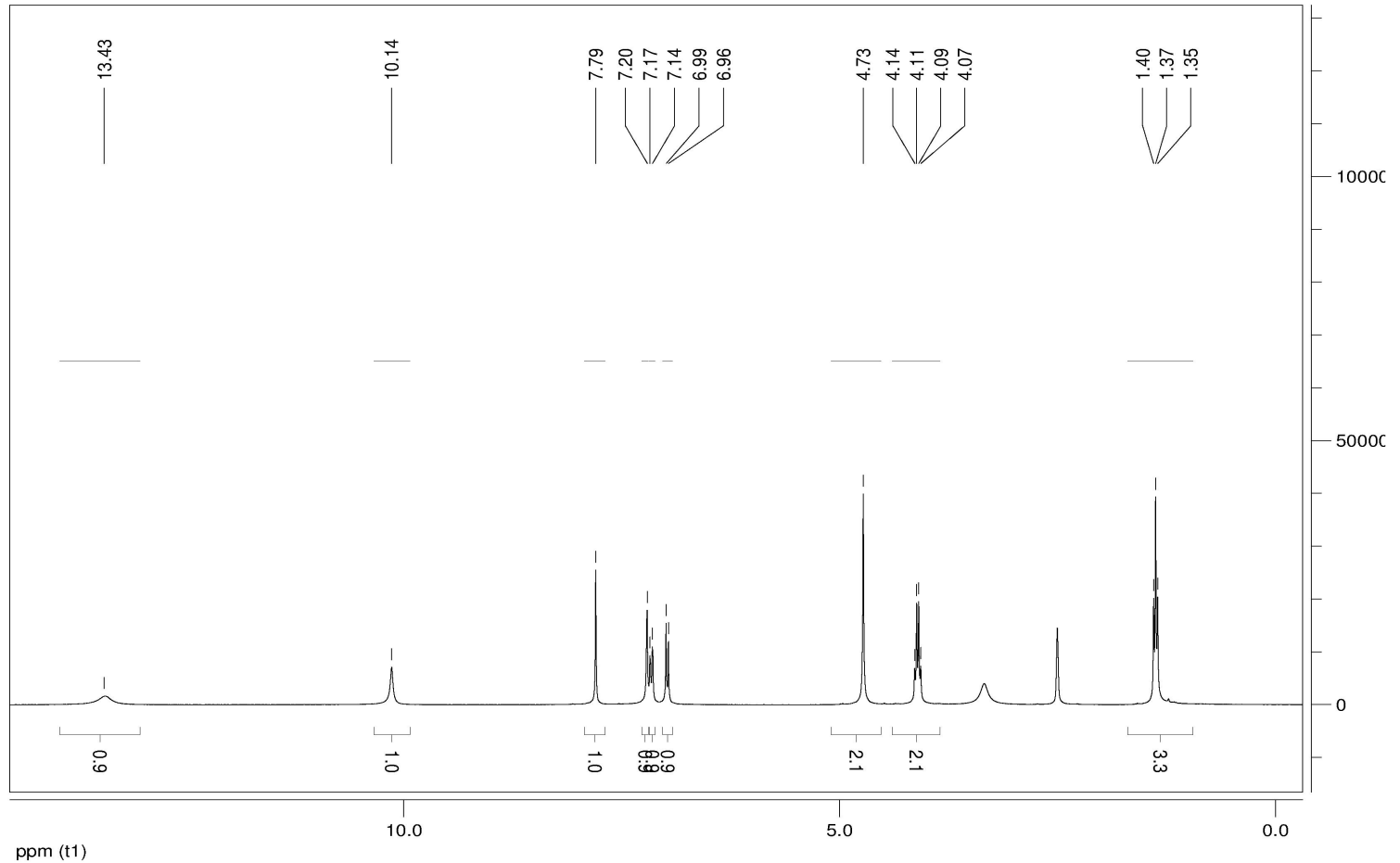

${ }^{13} \mathrm{C}$ NMR spectrum

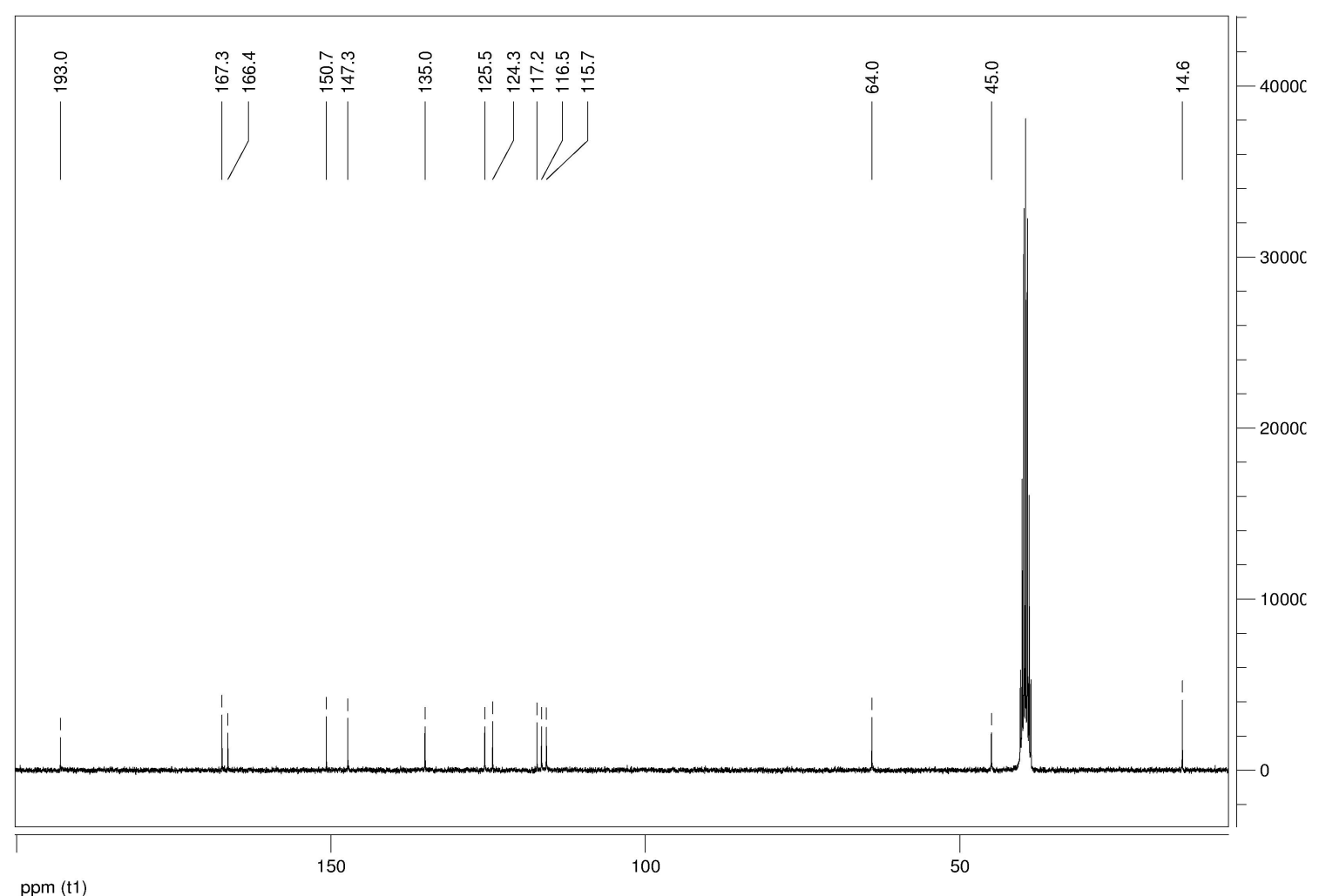




\section{SI References}

(1) Li, C., Plamont, M.-A., Sladitschek, H. L., Rodrigues, V., Aujard, I., Neveu, P., Le Saux, T., Jullien, L., and Gautier, A. (2017) Dynamic multicolor protein labeling in living cells. Chem Sci 8, 5598-5605.

(2) Plamont, M.-A., Billon-Denis, E., Maurin, S., Gauron, C., Pimenta, F. M., Specht,

C. G., Shi, J., Querard, J., Pan, B., Rossignol, J., Moncoq, K., Morellet, N., Volovitch, M., Lescop, E., Chen, Y., Triller, A., Vriz, S., Le Saux, T., Jullien, L., and Gautier, A. (2016) Small fluorescence-activating and absorption-shifting tag for tunable protein imaging in vivo. Proc Natl Acad Sci USA 113, 497-502. 